\title{
Wybory w cieniu pomarańczowej rewolucji
}

\section{Elections in the shadow of the Orange Revolution}

\section{Abstract}

The Parliamentary Elections in Ukraine in 2006 remained in the shadow of the 2004 Presidential Election and the Orange Revolution. The changes, which to a large extent resulted from the events of 2004-2005, influenced the shape of the Ukrainian political scene and Kiev's foreign and domestic policy. They have consolidated the ineffective "Third Way" policy, implemented in Ukraine, which is to allow the state to maintain a balance between the East and the West, and in fact strengthening the dependence, especially economic, on Russia. The new Electoral Ordinance (though it was expected to be beneficial for the democratization process) did not reduce the participation of oligarchs in the political life, but it changed the voting results. Politicians, chosen by citizens, have soon found themselves in the opposition's ranks. The forced coalitions and the lack of a charismatic leader would eventually result in a deepening state's weakness.

Keywords: Ukraine, Parliamentary Elections 2006, Orange Revolution

\section{Выборы в тени Оранжевой революции}

\section{Аннотация}

Парламентские выборы на Украине в 2006 г. остались в тени президентских выборов 2004 г. и Оранжевой революции. Перемены, которые преимущественно были 
следствием событий 2004-2005 гг., повлияли на политическую сцену, а также на внешнюю и внутреннюю политику Киева. Таким образом они упрочнили его неэффективную политику «третьего пути», которая должна была позволить государству сохранить равновесие между Востоком и Западом, а фактически увеличивавшую зависимость, прежде всего экономическую, от России. Новая избирательная система (хотя и ожидалось, что будет способствовать процессу демократизации) не ограничила участия олигархов в политической жизни, но изменила результаты голосования. Политики, которых выбрали избиратели, в конечном итоге оказались в рядах оппозиции, а принужденные коалиции и отсутствие харизматичного лидера привели со временем к большему ослаблению государства.

Ключевые слова: Украина, парламентские выборы 2006, Оранжевая революция

W ybory parlamentarne na Ukrainie w 2006 r. pozostawały w cieniu wydarzeń pomarańczowej rewolucji. Zmiany na politycznej scenie, które po nich nastąpiły, nie dokonały się w sposób tak spektakularny jak te, które zaszły w latach 2004-2005. Ukraińcy nie wyszli wówczas kolejny raz na Majdan, z dystansem przyjmując zakulisowe rozgrywki polityków. Tymczasem zmieniły one nie tylko skutki wyborczych decyzji społeczeństwa, ale również wpłynęły na politykę zagraniczną i wewnętrzną Kijowa, spychając go konsekwentnie w stronę Rosji.

\section{Zmiany w ordynacji wyborczej}

Kampania wyborcza do Rady Najwyższej Ukrainy oficjalnie rozpoczęła się 26 listopada 2005 r., na 120 dni przed głosowaniem zaplanowanym na 26 marca 2006 r.W tym dniu Ukraińcy mieli wybierać również deputowanych do Rady Najwyższej Autonomicznej Republiki Krymu, organów samorządu terytorialnego, czyli rad wiejskich, miejskich, rejonowych i obwodowych oraz przewodniczących wiejskich i miejskich jednostek terytorialnych (Notatka..., 2006, s. 7).

Głosowanie w $2006 \mathrm{r}$. miało odbyć się wedle nowych zasad. 25 marca 2004 r. zmieniono ordynację wyborczą z mieszanej na proporcjonalną i przyjęto trzyprocentowy próg wyborczy. Jakkolwiek rezygnacja z wyborów większościowych w okręgach jednomandatowych, z których uprzednio obsadzano połowę miejsc w parlamencie, miała poprawić przejrzystość kampanii, 
to zmiana ta była pozorna. Oligarchowie, startujący dotąd w okręgach jednomandatowych, nie zrezygnowali z kandydowania, lecz znaleźli miejsca na listach wybranych partii, $\mathrm{w}$ ten sposób legitymizujących ich działania. Ponadto wprowadzone zmiany mogły stać się zapowiedzią przyszłej bezpardonowej walki pomiędzy poszczególnymi ugrupowaniami o wpływ na tworzenie koalicji rządzącej oraz desygnowanie kandydata na stanowisko premiera.

Jak oceniała strona polska, nowa ordynacja miała być korzystna dla procesu demokratyzacji Ukrainy. Dalsze zmiany, wprowadzone 7 lipca 2005 r., miały przeciwdziałać „zastosowaniu administracji państwowej w wyborach”, manipulacjom biuletynami wyborczymi czy innym czynnikom, które wpłynęły na nieprawidłowości w wyborach prezydenckich w 2004 r. Ponadto o uczciwości głosowania miała przesądzić społeczna świadomość praw konstytucyjnych, które obroniono podczas pomarańczowej rewolucji i które tym samym hipotetycznie mogły nabrać szczególnego, wręcz symbolicznego znaczenia dla Ukraińców (Beziuk, 2005, s. 1-2).

Sami obywatele na przestrzeni kolejnych lat zmieniali opinie na temat tego jaki rodzaj ordynacji wyborczej byłby najlepszy dla ich kraju, a przyjęte rozwiązanie wyraźnie nie cieszyło się zaufaniem.

Tabela 1. Odsetek respondentów opowiadających się w danym roku za wskazanym systemem ordynacji wyborczej do parlamentu

\begin{tabular}{|l|c|c|c|c|}
\hline $\begin{array}{l}\text { Rodzaj ordynacji } \\
\text { uważanej za najlepszą } \\
\text { dla kraju }\end{array}$ & $\mathbf{2 0 0 1} \mathbf{r .}$ & $\mathbf{2 0 0 4} \mathbf{r .}$ & $\mathbf{2 0 0 6}$ r. & $\mathbf{2 0 0 7}$ r. \\
\hline większościowa & 32,3 & 25,2 & 33,5 & 33,2 \\
\hline proporcjonalna & 5,4 & 11,3 & 13,6 & 15,4 \\
\hline mieszana & 26,8 & 30,0 & 23,8 & 26,9 \\
\hline trudno powiedzieć & 35,5 & 33,5 & 29,1 & 24,6 \\
\hline
\end{tabular}

Źródło: Центр Разумкова, 2007a.

1 stycznia 2006 r. weszły także w życie zmiany do Konstytucji Ukrainy, przyjęte 8 grudnia 2004 r., będące jednym z warunków porozumienia, które wynegocjowano podczas obrad przy okrągłym stole podczas pomarańczowej rewolucji. Zgodnie z nimi Ukraina przeszła z systemu prezydenckiego do parlamentarno-prezydenckiego, co oznaczało zwiększenie roli Rady Najwyższej jako organu, który sprawował kontrolę nad pracami rządu i tworzącego 
go. Tym samym partie stały się podmiotami odpowiedzialnymi za politykę władzy wykonawczej i ustawodawczej na szczeblu centralnym i organów samorządu terytorialnego. Aby zrealizować ten cel niezbędne było powstanie koalicji, w skład której weszłaby co najmniej połowa z 450 deputowanych, gdyż konstytucja nie przewidywała powołania rządu mniejszościowego (Закон України..., 2005; Notatka..., 2006, s. 3).

Powierzenie formowania rządu parlamentowi nie cieszyło się wówczas popularnością w społeczeństwie. W 2006 r. zwolennikami takiego rozwiązania było 17,3 proc. Ukraińców, a aż 49,9 proc. badanych chciało, by odpowiedzialność w tym zakresie spoczywała na prezydencie. Ponieważ jednak w rok po wyborach parlamentarnych o siedem punktów procentowych wzrosło zaufanie w tej kwestii do Rady Najwyższej, można przyjąć że obywatele $\mathrm{z}$ wolna przekonywali się do takiego rozwiązania.

Tabela 2. W jaki sposób powinien być formowany rząd na Ukrainie?

\begin{tabular}{|l|c|c|c|}
\hline & $\mathbf{2 0 0 2} \mathbf{~ r .}$ & $\mathbf{2 0 0 6} \mathbf{~ r .}$ & $\mathbf{2 0 0 7} \mathbf{~ r .}$ \\
\hline $\begin{array}{l}\text { Rząd powinien być formowany wyłącznie } \\
\text { przez prezydenta }\end{array}$ & $10,2 \%$ & $14,5 \%$ & $16,1 \%$ \\
\hline $\begin{array}{l}\text { Rząd powinien być formowany przez } \\
\text { prezydenta i zatwierdzany przez parlament }\end{array}$ & $30,7 \%$ & $49,9 \%$ & $40,7 \%$ \\
\hline $\begin{array}{l}\text { Urząd powinien być formowany wyłącznie } \\
\text { przez parlament }\end{array}$ & $23,6 \%$ & $17,3 \%$ & $24,3 \%$ \\
\hline Inne rozwiązania (bez wskazania) & $3,0 \%$ & $3,9 \%$ & $3,1 \%$ \\
\hline Trudno odpowiedzieć & $32,5 \%$ & $14,4 \%$ & $15,8 \%$ \\
\hline
\end{tabular}

Źródło: Центр Разумкова, 2007.

Jednocześnie w ocenie obywateli Ukrainy wprowadzone zmiany były teoretyczne, nie przełożyły się na poprawę ich jakości życia. 39,9 proc. respondentów uważało, że nie wpłynęły na efektywność władzy, 49,7 proc. sądziło, że nie zaowocowały otwartością i przejrzystością procesu jej sprawowania, nie zwiększyły też odpowiedzialności rządzących wobec społeczeństwa (Центр Разумкова, 2006b) ${ }^{1}$. Ponadto 36,2 proc. pytanych nie spodziewało się, że zmiany w konstytucji pomogą państwu wyjść z kryzysu. Co prawda niemal

1 Przeciwne opinie prezentowało odpowiednio 23 proc. i 19,6 proc. pytanych. 
tyle samo osób (35,7 proc.) wyrażało przeciwny pogląd, jednak trudno było uznać wyniki badań za optymistyczne (Центр Разумкова, 2008)².

Na przełomie października i listopada 2006 r. Ukraińcy, pytani jak odnieśliby się do skasowania wniesionych poprawek i przywrócenia poprzedniego systemu rządów, w przeważającej mierze byli obojętni wobec takiej koncepcji (26,6 proc. badanych), nie potrafili odpowiedzieć ( 26,7 proc.) lub wręcz unikali odpowiedzi (2,2 proc.). 25,9 proc. badanych było negatywnie ustosunkowanych do takiej propozycji. Jedynie 18,6 proc. respondentów pozytywnie przyjęłoby takie rozwiązanie (Центр Разумкова, 2006a). Co ciekawe, gdy w tym samym czasie Ukraińcom zadano pytanie o to czy w ogóle wiedzą, iż w maju 2006 r. weszły w życie poprawki do konstytucji, na podstawie których prezydent stracił część swoich uprawnień na rzecz rządu i Rady Najwyższej, tylko 17 proc. osób oceniało swoją wiedzę na ten temat jako pełną. 22,8 proc. respondentów uważało, że są „do pewnego stopnia” poinformowani, 25,7 proc. „coś słyszało” na ten temat. Niemal tyle samo badanych (25,8 proc.) nie wiedziało nic (Центр Разумкова, 2006). Takie wyniki badań mogły świadczyć o tym, że z jednej strony dla rządzących niewiedza społeczeństwa mogła być stanem wygodnym - brak zaangażowania mógł minimalizować ryzyko ponownych protestów na szeroką skalę. Z drugiej strony nie można wykluczyć, że Ukraińcy po pomarańczowej rewolucji pragnęli stabilizacji i nie byli zainteresowani pogłębianiem wiedzy na temat sytuacji politycznej w kraju.

Pomiędzy 27 listopada a 25 grudnia 2005 r. za najważniejszą kwestię uważano stworzenie bloków i list wyborczych. Termin składania dokumentów umożliwiających rejestrację kandydatów w Centralnej Komisji Wyborczej (CKW) wyznaczono na 30 grudnia 2005 r., a następnie w ciągu siedmiu dni zapaść miała decyzja o akceptacji bądź odmowie rejestracji. Przedwyborczą agitację można było rozpocząć dopiero w momencie zatwierdzenia kandydata. Potencjalne powtórne wnioski o rejestrację partie i bloki wyborcze (a wg danych na koniec marca 2005 r. w Ministerstwie Sprawiedliwości było ich zarejestrowanych 126) mogły składać nie później niż 75 dni przed terminem wyborów, zatem 9 stycznia 2006 r. Ostateczny termin rejestracji wszystkich kandydatów mijał 13 stycznia 2006 r., trzy dni później do CKW wpłynąć

226,3 proc. nie miało wyrobionego zdania w tej kwestii. 
musiały listy przedstawicieli partii i bloków do składów komisji wyborczych. Ich skład mógł jeszcze ulec zmianie do 18 lutego 2006 r., a 19 lutego przyporządkowano określone numery na listach wyborczych partiom i blokom. Decyzje o zmianie deklarowanego przez kandydata przyporządkowania do danego ugrupowanie mogły zapadać jeszcze do 22 marca, więc na trzy dni przed głosowaniem.

Ostatecznie udział w wyborach zadeklarowało 45 partii, 7747 kandydatów - statystycznie 17 osób na jedno miejsce. Rezultaty głosowania Centralna Komisja Wyborcza była zobowiązana podać nie później niż do 10 kwietnia 2006 r., a listy wybranych osób miały zostać opublikowane w ciągu pięciu dni na łamach dzienników „Hołos Ukrajiny” („Голос України”) oraz „Urjadowyj kurier” („Урядовий кур'єр”) (Давидович, 2006, s. 318, 350-352; Beziuk, 2005, s. 2).

\section{Kampania wyborcza}

W ocenie Lubomyra Borysławskiego przedwyborczy etap w przypadku wyborów parlamentarnych 2006 r. rozpoczął się w zasadzie już po wyborach prezydenckich 2004-2005 r., które charakteryzowały przypadki „naruszenia prawa na wszystkich etapach procesu wyborczego". Mimo tych doświadczeń w 2006 r. społeczeństwo i politycy byli skłóceni, a wbrew oczekiwaniom doświadczenia pomarańczowej rewolucji nie przyniosły konsolidacji obywateli i rządzących wokół interesu państwa. Proces wyborczy „utonął” w politycznych zawirowaniach. Na plan pierwszy w dyskusji wysunęły się kwestie federalizmu, problemy językowe, stosunki międzykonfesyjne, retoryka antyeuropejska bądź wymierzona w NATO. Ponadto partie, które powinny być wyrazicielami ogólnonarodowych idei, stawały się prywatnymi przedsięwzięciami ich liderów, których imiona nosiły, tak jak Blok Julii Tymoszenko (BJuT), Blok Jurija Karmazina, Ludowy Blok Lytwyna, Blok Natalii Witrenko „Ludowa Opozycja”, Blok Łazarenki czy Polityczna Partia Ukrainy „Partia Polityki Putina"3. Szczególną rolę w kampanii wyborczej odegrały również ugrupowania skupione wokół Wiktora Juszczenki i Wiktora Janukowycza

3 „Partia Polityki Putina”, zarejestrowana 5 czerwca 2003 r., 5 grudnia 2008 r. zmieniła nazwę na „Ruś Jedyna” (Партия..., 2009; Партія..., 2009). 
- kontrkandydatów w wyborach prezydenckich 2004 r. (Бориславський, 2006, s. 82-83).

Niewątpliwie ogromny wpływ na sposób i efekty promocji kandydatów miał fakt, że wybory odbywały się w niespełna rok od wyborów prezydenckich, w okresie, gdy jedność pomarańczowej koalicji była już tylko wspomnieniem. Poza blokiem Wiktora Juszczenki pozostała m.in. Ukraińska Partia Narodowa, która utworzyła blok wespół z Partią Odrodzenia Wsi (Beziuk, 2005, 18 grudnia, s. 5) ${ }^{4}$, a prezydent i zdymisjonowana przezeń 8 września 2005 r. premier Julia Tymoszenko zabiegali o ten sam elektorat. Na sympatie wyborców wpływało także rozczarowanie politykami. Zwycięzcy z 2004 r. nie potrafili wprowadzić w życie zmian, jakich oczekiwało społeczeństwo, a poparcie dla Juszczenki systematycznie malało, by w 2006 r. spaść poniżej 10 proc. (Сорока, 2010). Według badań opinii publicznej z października 2008 r. 75 proc. obywateli uważało, że nie wykonuje on swoich przedwyborczych obietnic. 13,3 proc. badanych podzielało tę opinię, lecz sądziło że ktoś mu to uniemożliwia, a zaledwie 3,1 proc. było zdania, że prezydent wywiązywał się ze zobowiązań (Центр Разумкова, 2008a). Nieco lepiej oceniana była Julia Tymoszenko, z której działań w zakresie realizacji obietnic wyborczych zadowolonych było 10,5 proc. respondentów. 50,1 proc. uważało, że Tymoszenko ich nie spełnia, a kolejnych 29 proc. podzielało ten pogląd, sądząc jednak że nie ponosi za to odpowiedzialności (Центр Разумкова, 2008b).

Jak odnotowała Ambasada RP w Kijowie, w grudniu 2005 r. szansę na przekroczenie 3 proc. progu wyborczego miało sześć spośród 45 startujących w wyborach partii i bloków politycznych (Beziuk, 2005, s. 2). Tym samym żadna z nich nie miałaby możliwości utworzenia samodzielnego rządu, lecz nie musiało to przesądzać o trudnościach w nawiązaniu przyszłej współpracy między politykami. Wydawało się, że rozbieżności programowe pomiędzy

${ }^{4}$ W skład Bloku Nasza Ukraina weszły Narodowy Sojusz Nasza Ukraina (z J. Jechanurowem), Partia Przemysłowców i Przedsiębiorców Ukrainy (z A. Kinachem, szefem Rady Bezpieczeństwa i Obrony Ukrainy), Ludowy Ruch Ukrainy (z B. Tarasiukiem, ministrem spraw zagranicznych), Kongres Ukraińskich Nacjonalistów (z O. Iwczenko, szefem Naftohazu), Partia Sojusz Chrześcijańsko-Demokratyczny (z W. Stretowyczem) i część członków Republikańskiej Partii „Zjednoczenie” (z A. Matwijenką, zastępcą szefa Sekretariatu Prezydenta). (Notatka..., 2006, s. 2). 
poszczególnymi ugrupowaniami nie były na tyle duże, by ją uniemożliwić. Można było raczej przypuszczać, że to względy ambicjonalne liderów staną na przeszkodzie tworzeniu koalicji.

$\mathrm{Na}$ największe poparcie tuż po rozpoczęciu kampanii wyborczej mogły liczyć Partia Regionów (PR) (27,8 proc.), Blok Juszczenki „Nasza Ukraina” (NU) (15,7 proc.), Blok Julii Tymoszenko (14,7 proc.), Komunistyczna Partia Ukrainy (KPU) (6,1 proc.), Socjalistyczna Partia Ukrainy (SPU) (5,9 proc.) i Blok Wołodymyra Łytwyna (5,5 proc.). Na granicy progu wyborczego miał balansować lewicowy Blok Natalii Witrenko, na który składały się Progresywna Partia Socjalistyczna i Związek Rosyjsko-Ukraiński, ale też nie wykluczano, że wymagane poparcie uzyska koalicja wyborcza partii Reformy i Porządek Wiktora Pynzenyka i Partii „Pora”, na czele której stanął były bokser i biznesmen zaangażowany w wydarzenia pomarańczowej rewolucji Witalij Kliczko. Jako niewielkie oceniano szanse opozycyjnego Bloku „Nie Tak!”, który podczas kampanii wyborczej posługiwał się barwami charakterystycznymi dla flagi Federacji Rosyjskiej i głosił postulaty wejścia Ukrainy do Wspólnej Przestrzeni Gospodarczej Rosji, Białorusi i Kazachstanu (Beziuk, 2005, s. 2-6; Партія..., 2002). Przypuszczenia te potwierdzały wyniki sondażowe opublikowane na dwa tygodnie przed głosowaniem, w ostatnim dopuszczanym przez prawo terminie.

Tabela 3. Dynamika rankingów wyborczych partii politycznych i bloków w okresie listopad 2005 r. - marzec 2006 r.

\begin{tabular}{|l|c|c|c|c|}
\hline & \multicolumn{4}{|c|}{ Procentowe poparcie dla poszczególnych ugrupowań } \\
\cline { 2 - 5 } & $\mathbf{1 7 - 2 9 . 1 1 . 2 0 0 5}$ r. & $\mathbf{1 7 - 3 0 . 1 2 . 2 0 0 5}$ r. & $\mathbf{1 9 - 3 1 . 0 1 . 2 0 0 6}$ r. & $\mathbf{2 6 . 0 2 - 6 . 0 3 . 2 0 0 6}$ r. \\
\hline Partia Regionów & $27,8 \%$ & $31,0 \%$ & $28,9 \%$ & $30,04 \%$ \\
\hline Blok „Nasza Ukraina” & $15,7 \%$ & $13,0 \%$ & $18,0 \%$ & $17,1 \%$ \\
\hline Blok Julii Tymoszenko & $14,7 \%$ & $16,2 \%$ & $14,2 \%$ & $16,9 \%$ \\
\hline $\begin{array}{l}\text { Socjalistyczna Partia } \\
\text { Ukrainy }\end{array}$ & $5,9 \%$ & $4,8 \%$ & $4,6 \%$ & $5,4 \%$ \\
\hline $\begin{array}{l}\text { Komunistyczna Partia } \\
\text { Ukrainy }\end{array}$ & $6,1 \%$ & $3,8 \%$ & $3,7 \%$ & $3,7 \%$ \\
\hline $\begin{array}{l}\text { Blok Wołodymyra } \\
\text { Łytwyna }\end{array}$ & $5,5 \%$ & $3,9 \%$ & $3,8 \%$ & $3,4 \%$ \\
\hline Blok Natalii Witrenko & $2,8 \%$ & $3,8 \%$ & $2,2 \%$ & $1,8 \%$ \\
\hline
\end{tabular}




\begin{tabular}{|l|c|c|c|c|}
\hline & \multicolumn{4}{|c|}{ Procentowe poparcie dla poszczególnych ugrupowań } \\
\cline { 2 - 5 } & $\mathbf{1 7 - 2 9 . 1 1 . 2 0 0 5}$ r. & $\mathbf{1 7 - 3 0 . 1 2 . 2 0 0 5}$ r. & $\mathbf{1 9 - 3 1 . 0 1 . 2 0 0 6}$ r. & $\mathbf{2 6 . 0 2 - 6 . 0 3 . 2 0 0 6}$ r. \\
\hline $\begin{array}{l}\text { Blok Obywatelski „Pora” } \\
\text { - PRP }\end{array}$ & $0,6 \%$ & $1,3 \%$ & $1,0 \%$ & $2,3 \%$ \\
\hline $\begin{array}{l}\text { Opozycyjny Blok „Nie } \\
\text { Tak!” }\end{array}$ & $1,0 \%$ & $1,0 \%$ & $0,7 \%$ & $0,9 \%$ \\
\hline $\begin{array}{l}\text { Ukraiński Narodowy } \\
\text { Blok Kostenki - Pluszcza }\end{array}$ & $0,7 \%$ & $0,5 \%$ & $0,3 \%$ & $1,4 \%$ \\
\hline Partia Wicze & $2,2 \%$ & $3,5 \%$ & $2,4 \%$ & $3,3 \%$ \\
\hline
\end{tabular}

Źródło: Beziuk, 2006, s. 1-2.

Niezwykle interesująco prezentował się rozkład sympatii politycznych według regionów Ukrainy, przy czym na przykład Konsulat Generalny RP w Charkowie zwracał uwagę na specyfikę kampanii wyborczej na wschodzie Ukrainy, ze względu na „pewną odmienność problemów uznawanych za priorytetowe”. Wskazywano na dostosowywanie się polityków do oczekiwań wyborców, czego przykładem był fakt, iż podczas wizyty w Charkowie Wołodymyr Łytwyn nie propagował hasła wyborczego swojego bloku „zgody politycznej niebieskich z pomarańczowymi”, lecz podkreślał zamiar przeniesienia do tego miasta siedziby Sądu Konstytucyjnego. Julia Tymoszenko z kolei akcentowała plany wdrożenia programów ratunkowego i rozwojowego dla największych lokalnych zakładów przemysłu ciężkiego, choć, podobnie jak socjalista Ołeksandr Moroz, nie przewidywała ich prywatyzacji. Idea ta była zgoda z oczekiwaniami społeczeństwa, uznającego, zdaniem dyplomatów, własność państwową za „stan normalny”, gwarancję bezpieczeństwa socjalnego i zatrudnienia. Niechęć do zmian systemowych na wschodzie Ukrainy była wyraźnie silniejsza niż pragnienie „powrotu do przeszłości”, czym można było tłumaczyć znaczne poparcie dla PR.

Wyborcy nie krytykowali łączenia planów odrodzenia potęgi gospodarczej wschodu z postulatami wzmocnienia więzi z Rosją, Białorusią i Kazachstanem, czego domagał się m.in. Blok „Nie Tak!”. Jak się wydaje nie tylko dlatego, że relacje te dominowały w sferze gospodarczej, ale też przestarzałe, niekonkurencyjne technologie i uzależnienie od rynków państw WNP skutkowały niechęcią wobec integracji z krajami Europy Zachodniej. Ponadto w sytuacji, gdy po wygranych wyborach „pomarańczowi” nie realizowali swoich haseł, silniejsze niż obawa przed uzależnieniem od Moskwy 
okazywało się pragnienie utrzymania może nie najlepszej, ale stabilnej sytuacji (Książek, 2006, s. 1-2).

Tabela 4. Zróżnicowanie regionalne poparcia dla partii politycznych na Ukrainie w $2006 \mathrm{r}$.

\begin{tabular}{|l|c|c|c|c|c|}
\hline & \multicolumn{5}{|l}{$\begin{array}{l}\text { Procentowe poparcie dla poszczególnych ugrupowań wg } \\
\text { regionów }\end{array}$} \\
\cline { 2 - 6 } & Zachód & $\begin{array}{l}\text { Centrum } \\
\text { i północ }\end{array}$ & Wschód & $\begin{array}{c}\text { Donbas (Donieck } \\
\text { i obwód łuhański) }\end{array}$ & Południe \\
\hline Partia Regionów & $3,4 \%$ & $12,5 \%$ & $43,8 \%$ & $82,6 \%$ & $38,3 \%$ \\
\hline Blok „Nasza Ukraina” & $36,6 \%$ & $21,0 \%$ & $7,5 \%$ & $1,9 \%$ & $8,7 \%$ \\
\hline Blok Julii Tymoszenko & $20,1 \%$ & $29,7 \%$ & $8,1 \%$ & $1,1 \%$ & $10,6 \%$ \\
\hline $\begin{array}{l}\text { Socjalistyczna Partia } \\
\text { Ukrainy }\end{array}$ & $4,2 \%$ & $10,7 \%$ & $3,1 \%$ & $0,4 \%$ & $3,0 \%$ \\
\hline $\begin{array}{l}\text { Komunistyczna Partia } \\
\text { Ukrainy }\end{array}$ & $1,1 \%$ & $4,4 \%$ & $5,3 \%$ & $2,3 \%$ & $5,3 \%$ \\
\hline $\begin{array}{l}\text { Blok Wołodymyra } \\
\text { Łytwyna }\end{array}$ & $2,2 \%$ & $5,4 \%$ & $3,4 \%$ & $0,4 \%$ & $3,4 \%$ \\
\hline Blok Natalii Witrenko & $0,3 \%$ & $0,8 \%$ & $2,8 \%$ & $3,0 \%$ & $3,8 \%$ \\
\hline $\begin{array}{l}\text { Blok Obywatelski „Pora” } \\
\text { - PRP }\end{array}$ & $4,5 \%$ & $2,7 \%$ & $1,6 \%$ & 0 & $1,9 \%$ \\
\hline $\begin{array}{l}\text { Opozycyjny Blok „Nie } \\
\text { Tak!” }\end{array}$ & $0,3 \%$ & $1,0 \%$ & $0,9 \%$ & $0,8 \%$ & $1,9 \%$ \\
\hline $\begin{array}{l}\text { Ukraiński Narodowy Blok } \\
\text { Kostenki - Pluszcza }\end{array}$ & $2,8 \%$ & $2,2 \%$ & $0,3 \%$ & 0 & $0,4 \%$ \\
\hline Partia Wicze & $1,4 \%$ & $1,4 \%$ & $2,8 \%$ & $0,4 \%$ & $2,7 \%$ \\
\hline
\end{tabular}

Źródło: Beziuk, 2006.

Partia Regionów cieszyła się największą popularnością w obwodach uznawanych za prorosyjskie - charkowskim, dniepropietrowskim, zaporoskim, w Donbasie oraz w Autonomicznej Republice Krymu, obwodach odeskim, mikołajewskim i chersońskim. Ugruntowywało to przekonanie, iż Wiktor Janukowycz jest politykiem, którego powiązania z Kremlem mogą mieć wpływ na ukraińską politykę. „Nasza Ukraina” - blok o centroprawicowym profilu - miała najwięcej zwolenników w zachodnich obwodach kraju, utożsamianych $\mathrm{z}$ nacjonalistycznymi poglądami, natomiast na wschodzie, południu i w centrum rywalizowała o głosy z Blokiem Julii Tymoszenko. Bardziej umiarkowany, ale wciąż postrzegany jako proukraiński i proeuropejski 
program byłej pani premier mógł okazać się tam atrakcyjniejszy, niż propozycje prezydenta. Pozostałe ugrupowania mogły liczyć na zaledwie kilkuprocentowe poparcie.

Można wnioskować, że wydarzenia pomarańczowej rewolucji ugruntowały podział sympatii pomiędzy wschodnimi i zachodnimi obwodami. Otoczenie Juszczenki nie potrafiło pozyskać sobie zwolenników na wschodzie i południu kraju, a brak atrakcyjnego programu politycznego przełożył się na przyszły sukces „,biało-niebieskich”, którzy, jak zauważała Elżbieta Beziuk, w toku kampanii zdobywali elektorat nie tyle dzięki własnej aktywności, co dzięki brakowi sukcesów po stronie władz centralnych (Beziuk, 2006, s. 3). Blok „Nasza Ukraina”, pod hasłem „Mamy jedną Ukrainę”, nadal szukał oparcia w retoryce znanej z pomarańczowej rewolucji, popełniając przy tym błędy wizerunkowe. Społeczeństwo było zmęczone powielaniem haseł z kampanii prezydenckiej, szczególnie że miało możliwość weryfikacji ich realizacji w praktyce. Ponadto NU była w zasadzie pozbawiona charyzmatycznego lidera. Co prawda z numerem 1 na liście wyborczej zdecydowano się umieścić premiera Jurija Jechanurowa, ale nie zrezygnowano z „postaci, które przyczyniły się do kryzysu kadrowego w ekipie W. Juszczenki”, m.in. Petra Poroszenki. Zdawano sobie przy tym sprawę z konieczności stworzenia w przypadku wygranych wyborów koalicji, dlatego nie chciano podejmować zdecydowanej walki z oponentami, zachowując wobec nich umiarkowaną pozycję (Beziuk, 2005, s. 3; Notatka..., 2006, s. 3-4).

Znacznie lepiej wykorzystała swoją szansę Julia Tymoszenko, która postawiła na aktywną kampanię prowadzoną w regionach i kreowała swój wizerunek jako polityka zaangażowanego w problemy społeczne. Zjazd jej Bloku [na który składały się dwie partie - Batkiwszczyna i Ukraińska Partia Socjaldemokratyczna Wasyla Onopenko, a także część członków Republikańskiej Partii „Zjednoczenie”, skupionych wokół dysydenta Łewka Łukjanenki (Українська народна...; Соціал-демократична...; Батьківщина...)] „,charakteryzował się doskonałą organizacją, podkreślając wiodącą rolę w Bloku oraz perfekcyjność lidera”. Trzeba zarazem zauważyć, że zaprezentowany wówczas program miał populistyczny charakter, zdominowały go hasła, a zabrakło konkretnych propozycji działania. Jak się zdaje to charyzma Tymoszenko miała zastąpić konkretne postulaty. Na listach wyborczych BJuT pierwsze miejsca zajęły osoby zaangażowane w życie społeczne i wiązane 
z konkretnymi środowiskami. W ten sposób stworzono wrażenie, że Blok poświęca uwagę różnorodnym aspektom życia obywateli. Zarazem zamierzano „przemycić” nazwiska „reprezentantów biznesu” (jak można przypuszczać także oligarchów) jako „ekspertów parlamentarnych”. Mimo to wydaje się, że Tymoszenko ostrożnie i umiejętnie rozgrywała tę partię: zrezygnowała m.in. z umieszczenia na listach wyborczych kandydatów mogących jednoznacznie budzić kontrowersje (Beziuk, 2005, s. 2-3).

W opozycji do zwolenników pomarańczowej rewolucji pozostawała Partia Regionów, usiłująca (przynajmniej teoretycznie) pogodzić dwie odmienne koncepcje polityczne. Z jednej strony postulowano zbliżenie z Unią Europejską i NATO; z drugiej - zacieśnianie więzów z Rosją, nadanie statusu języka oficjalnego językowi rosyjskiemu czy federalizm. Hasła te, mimo iż wymagały zmian w Konstytucji, mogły okazać się atrakcyjne dla licznej mniejszości rosyjskiej. Zaufanie mogło także budzić opublikowanie przez Partię Regionów przedwyborczego programu pod hasłem „Dobrobyt - narodowi! Władza - regionom!”. Równocześnie należy podkreślić, że ugrupowanie zyskiwało na popularności w przedwyborczych rankingach pomimo braku większej aktywności jego lidera i samych członków. Można zatem wnioskować, że główną przyczyną rosnącego poparcia był jego spadek w przypadku obozu rządzącego i przejmowanie rozczarowanego elektoratu NU. Niewątpliwie ogromne znaczenie miała też centralizacja struktury partii i jej duże zdolności mobilizacyjne, choć Ambasada RP w Kijowie zauważała, że w przypadku PR praktyka i teoria nie zawsze szły z sobą w parze. Postulując rozdzielenie władzy i biznesu, równocześnie na listach wyborczych umieszczono Rinata Achmetowa, co, jak przypuszczano, wskazywało na powiązania Janukowycza i oligarchy (Beziuk, 2005, s. 3; Тексm..., 2005).

W grudniu 2005 r. czwartą pod względem popularności w rankingach wyborczych była Komunistyczna Partia Ukrainy, a jednak, jak prognozowano, wybory w 2006 r. mogły okazać się „ostatnim dla KPU sprawdzianem wyborczym”. Nie spodziewano się, aby ugrupowanie Petra Symonenki weszło w skład jakiejkolwiek koalicji. Przyczyną było kurczenie się elektoratu partii o silnie zideologizowanym programie. Można przypuszczać, że utrzymywała się ona na arenie politycznej w dużej mierze dzięki zaoferowaniu miejsc na listach wyborczych przedstawicielom małego i średniego biznesu. Nie byli to gracze liczący się w walce o władzę, ale mieli ambicje, by pretendować do tego 
grona i w tej sytuacji ich przekonania mogły znaleźć się na dalszym planie (Beziuk, 2005, s. 4; Notatka..., 2006, s. 2-3). Był to kolejny przypadek, gdy uwidaczniały się zależności pomiędzy światem polityki i przedsiębiorcami. Miały one niebagatelny wpływ na decyzje podejmowane przez rządzących szczególnie w sytuacjach, gdy w grę mogły wchodzić ewentualne straty finansowe, takie jak wynikające $\mathrm{z}$ osłabienia relacji z Rosją.

Z kolei Socjalistyczna Partia Ukrainy, z Ołeksandrem Morozem na czele, chciała „zbudować Europę na Ukrainie” i akcentowała treści lewicowe i socjalne. SPU, mimo iż w rządzie Jechanurowa miała swoich trzech ministrów, dystansowała się od poczynań władzy, akcentując odmienność programową od „Naszej Ukrainy”. Podobnie jak Partia Regionów zwracała uwagę na kwestie językowe, istotne przede wszystkim dla mniejszości rosyjskiej, ale i rosyjskojęzycznych Ukraińców. Miał to być sposób pozyskania głosów we wschodnich regionach kraju, gdzie ugrupowanie Juszczenki nie cieszyło się większą popularnością. Jednocześnie socjaliści nie przekreślali możliwości przyszłej współpracy z obozem pomarańczowych, a Moroz nie krył, że liczy na objęcie stanowiska spikera Rady Najwyższej (Beziuk, 2005, s. 4; Notatka..., 2006, s. 2-3).

Chęć podjęcia współpracy z „wszystkimi konstruktywnymi siłami na scenie politycznej" deklarował Blok Wołodymyra Łytwyna, w skład którego weszły Ukraińska Ludowa Partia Demokratyczna, Partia „Sprawiedliwość” Serhija Tihipki (w 2004 r. wspierająca Janukowycza) i Partia Ludowa. Ugrupowanie budowało swój wizerunek jako mogącego stać się gwarantem równowagi politycznej, troszczącego się o duchowy i kulturalny rozwój narodu. Jednakże zarówno otoczenie Juszczenki, jak i Janukowycza krytykowały jego działania. Prawdopodobnie na niechętne postawy wobec Bloku Łytwyna znacząco wpływał fakt, iż jego lider, pełniąc funkcję przewodniczącego Rady Najwyższej, był politykiem ocenianym jako niezależny w swych działaniach i decyzjach, co za tym idzie mógł być potencjalnie groźnym przeciwnikiem w politycznych zmaganiach. Trudno wnioskować czy brak spodziewanej obecności na listach wyborczych Bloku Łytwyna zięcia Leonida Kuczmy, Wiktora Pinczuka, mógł być dowodem na niechęć lidera do dopasowywania się do już istniejących układów czy odcięcia się od oligarchów, ale niewątpliwie był to argument za jego nieprzewidywalnością (Beziuk, 2005, s. 5). 


\section{Kampania w cieniu dymisji premiera i polityki zagranicznej}

Zmiana ordynacji wyborczej sprzyjała reformowaniu sceny politycznej, akcentowaniu przez partie polityczne różnic programowych, ale też rozgrywkom politycznym. Priorytetem dla zwolenników Tymoszenko było osiągnięcie jak najwyższego poparcia w wyborach, przekładającego się na mocną pozycję podczas negocjacji z innymi ugrupowaniami. Stąd wynikał pozorny brak konsekwencji w stosunku do ekipy rządzącej - deklarując chęć współpracy z Juszczenką, równocześnie krytykowano Jurija Jechanurowa. Co więcej, BJuT wsparł wniosek o zdymisjonowaniu jego rządu (Beziuk, 2005, s. 4).

Decyzja ta, podjęta przez Radę Najwyższą, była postrzegana jako demonstracja siły i próba zdeprecjonowania prezydenta i rządu. O dymisji zadecydowano „głosami opozycyjnych frakcji Regionów, Socjaldemokratycznej Partii Ukrainy (zjednoczonej), KPU oraz frakcji J. Tymoszenko i deputowanych związanych z przewodniczącym parlamentu W. Łytwynem" (Notatka..., 2006, s. 3). Mimo to nie doprowadzono sprawy do końca i rząd wykonywał swoje zadania w niezmienionym zakresie. Deputowani bowiem, korzystając ze znowelizowanych przepisów konstytucji, popełnili kardynalny (bądź zamierzony) błąd: projekt poddawany pod głosowanie powinno podpisać 150 deputowanych, a uczyniło to jedynie dwóch posłów KPU.Zarazem Sąd Konstytucyjny nie mógł stwierdzić naruszenia procedur i uznać głosowania za nieważne, gdyż nie posiadając pełnego składu nie mógł podejmować wiążących decyzji. W tej sytuacji prezydent znalazł się w opozycji do Rady Najwyższej i zdecydowanie wystąpił w obronie rządu, domagając się anulowania decyzji o dymisji, po czym wycofał swój podpis z memorandum o współpracy z Janukowyczem, podpisanego we wrześniu 2005 r. Wiktor Juszczenko otwarcie potępił też „głosowanie BJuT zgodne z obozem postkuczmowskim i komunistami", a ekipa Tymoszenko, popierając dymisję Jechanurowa, naraziła się na spadek popularności, przede wszystkim w zachodnich obwodach kraju, gdzie wciąż żywa była idea jedności pomarańczowego obozu (Notatka..., 2006, s. 3-4).

Po wydarzeniach na Majdanie w latach 2004-2005 można było spodziewać się, że problematyka współpracy z Unią Europejską i Paktem Północnoatlantyckim będzie podnoszona jako uwiarygodniająca polityków 
akcentujących brak zgody na rosyjską ingerencję w wewnętrzne sprawy Ukrainy. Tymczasem tylko jeden z bloków zdecydował się na sięgnięcie do takiej argumentacji - ugrupowanie Kostenki i Pluszcza deklarowało wolę wprowadzenia Ukrainy do NATO. Ani Nasza Ukraina, ani BJuT nie wypowiedziały się w wiążący i jednoznaczny sposób w tej kwestii, co, jak należy przypuszczać, rozczarowało zwolenników eurointegracji. Brak aktywności na tej płaszczyźnie zacierał różnice pomiędzy „pomarańczowymi” a partiami opozycyjnymi, które (jak Blok „Nie Tak!” Leonida Krawczuka czy Blok Natalii Witrenko) były nieprzychylne członkostwu Ukrainy w NATO, a w najlepszym wypadku zapowiadały utrzymanie dotychczasowej formuły współpracy, potencjalne członkostwo odsuwając w bliżej nieokreśloną przyszłość (Notatka..., 2006, s. 4).

Z kolei Partia Regionów, jak się wydaje pomna doświadczeń z 2004 r. i świadoma oczekiwań części społeczeństwa, nie głosiła postulatów antyunijnych czy antynatowskich, nadmieniając o korzyściach płynących z pozablokowego statusu Ukrainy. W ten sposób zwiększała wydatnie swoje szanse na poparcie ze strony obywateli prezentujących „przychylną neutralność” wobec struktur zachodnioeuropejskich, nie ryzykując utraty twardego elektoratu. Nowych wyborców starano się raczej pozyskać poprzez hasła ekonomiczne i socjalne, atrakcyjne dla osób rozczarowanych polityką rządu (Zajączkowski, 2006, s. 2).

W zasadzie dwie liczące się siły, Partia Regionów i „Nasza Ukraina”, skupiły się na utrzymaniu poparcia dotychczasowego elektoratu, nie stworzyły nowych haseł czy technologii wyborczych, a aktywność poszczególnych sztabów była niewielka i niemal pozbawiona „elementów programowych oraz poważnych debat nt. przyszłości państwa” (Zajączkowski, 2006, s. 2). To Julia Tymoszenko postawiła na aktywność w zakresie prób przejęcia głosów wyborców Natalii Witrenko i ugrupowań lewicowych. BJuT wyróżniały też deklaracje na temat przyszłej koalicji rządowej, podkreślające jej zależność od rozkładu głosów w wyborach i stanowiska poszczególnych partii. Nawet jeśli brak tu było konkretnych zobowiązań, to na tle innych ugrupowań, niepodejmujących tego tematu, blok Tymoszenko prezentował troskę o przyszły kształt rządów, podnosząc swą wiarygodność. Była premier skupiała uwagę na centralnych i południowych obwodach kraju, ale też była jedynym politykiem, który w toku kampanii odwiedził wszystkie obwody, biorąc 
udział w spotkaniach z wyborcami. Jak się okazało, taktyka ta przyniosła BJuT oczekiwane rezultaty, choć można też rozważać na ile na przewagę nad „Naszą Ukrainą” przełożyły się oskarżenia jakie Tymoszenko skierowała pod adresem tego bloku w ostatnim tygodniu kampanii wyborczej.

Kampania przed wyborami 2006 r. była skoncentrowana wokół problematyki socjalnej, a w kwestiach międzynarodowych na relacjach z Moskwą i NATO. Politycy skupiali się na dotarciu do ustalonego już elektoratu, a jeśli chciano pozyskiwać nowych wyborców, to czyniono to w obrębie utrwalonego podziału na „pomarańczowych” i „biało-niebieskich”. Znaczna część kampanii była oceniana jako łagodniejsza niż ta prowadzona w 2004 r., obiektywna, pozbawiona „działań, które miałyby realny, negatywny wpływ na rezultat wyborczy", umiarkowanie zmanipulowana, choć niedostatecznie zrównoważona. Dziennikarze rzadziej niż w poprzednich latach demonstrowali swoje sympatie polityczne. Wyjątek stanowił tu „Kanał 5” powiązany z osobą Petra Poroszenki, a tym samym z „Naszą Ukrainą”. Z kolei należące do „grupy donieckiej” TRK Ukraina i TN NTN forowały kandydatów opozycyjnych, podobnie jak kanały rosyjskiej telewizji powszechnie dostępne na znacznym obszarze kraju (Notatka..., 2006, s. 6-7).

Nie wskazywano na próby zastraszania polityków, sięgania do administracyjnych środków nacisku, marginalnie korzystano z treści mogących kompromitować kontrkandydatów. Wykorzystano je w zasadzie tuż przed głosowaniem, zatem w momencie, gdy niewątpliwie najbardziej zapadły w pamięci wyborców. Wtedy to BJuT zarzucił „Naszej Ukrainie” „wykorzystanie w dniu wyborów specjalnego przesyłowego serwisu komputerowego", który miał umożliwić sfałszowanie wyników (Zajączkowski, 2006, s. 2). W telewizji emitowano filmy przypominające o próbie otrucia Wiktora Juszczenki, za co odpowiedzialnością obarczano jego kontrkandydata Wiktora Janukowycza. 10 marca 2006 r. pokazano też film Niebezpieczeństwo. Straszna prawda traktujący o Partii Regionów i klanie donieckim. Jednocześnie Juszczenko podkreślał na antenie potrzebę utworzenia koalicji w oparciu o interesy narodowe, a nie waśnie międzypartyjne, wymierzonej w politycznych oponentów. 


\section{Kampania w cieniu Moskwy}

Co istotne, konflikt pomiędzy władzą wykonawczą a ustawodawczą (przy zaangażowaniu weń władzy sądowniczej) rozgrywany był w cieniu Moskwy. Oficjalnym powodem żądania dymisji Jechanurowa było fiasko rozmów w sprawie ukraińsko-rosyjskiego porozumienia gazowego, co wraz z decyzją o wstrzymaniu importu artykułów spożywczych z Ukrainy do Rosji przełożyło się na polityczną atmosferę nad Dnieprem. Z perspektywy władz rosyjskich konflikty wśród niedawnych sojuszników były pożądane, mogły bowiem wpływać na marginalizację przez Ukraińców kwestii integracji z Unią Europejską i NATO. Wśród celów, jakie stawiał przed sobą Kreml, było utrzymanie w orbicie swoich wpływów państw tzw. bliskiej zagranicy - dawnych republik radzieckich. Tymczasem już rewolucja róż w Gruzji poważnie zachwiała status quo, a pomarańczowa rewolucja na Ukrainie ugruntowała pęknięcia w systemach ustanowionych w latach 90. XX w. Potencjalne zbliżenie Kijowa $\mathrm{z}$ Zachodem byłoby postrzegane nie tylko jako jego strata, ale także wygrana zachodnich służb specjalnych, gdyż to one były podejrzewane o inspirowanie „kolorowych rewolucji”.

Można przypuszczać, że już u zarania sporu gazowego Moskwa spodziewała się, że wstrzymanie dostaw gazu będzie niezwykle ważną kwestią dla społeczeństwa, ale też przedmiotem debaty polityków, których stanowiska w tej sprawie nie będą zgodne. Ukraińcy przyzwyczajeni byli do tanich surowców energetycznych i mieli świadomość uzależnienia tak odbiorców prywatnych, jak i przemysłu od dostaw przede wszystkim z Rosji. Dlatego wzrost cen nie był postrzegany w kategoriach ekonomicznych, a przede wszystkim politycznych. W tej sytuacji uważano, że problem będzie można rozwiązać "przy pomocy jednorazowej, politycznej decyzji” i ugrupowania, które takie rozstrzygnięcie obiecywały, mogły niewątpliwie cieszyć się poparciem (Książek, 2006, s. 2).

Zainteresowanie koniecznością utrzymania konsensusu wobec reform na Ukrainie podczas kryzysu wyrażał nawet Javier Solana, który kilkakrotnie prowadził w tej sprawie rozmowy z Juszczenką (Zajączkowski, 2006). Tymczasem Juszczenko, Jurij Jechanurow czy minister energetyki Iwan Płaczkow uważali, że rozmowy na temat dostaw gazu powinny skupiać się wokół argumentów ekonomicznych, nie politycznych. Sekretarz Rady Bezpieczeństwa 
i Obrony chciał, by „konsorcjum zarządzające gazociągami stało się kartą przetargową w rozmowach", a Wołodymyr Łytwyn przekonywał, że to Kijów winien jest niepowodzeń w negocjacjach ze stroną rosyjską, co mogło wpłynąć na opinię wyborców, pragnących przede wszystkim stabilnej sytuacji w tym zakresie. Ponadto sugestia, jakoby kryzysu nie udało się rozwiązać przed marcowymi wyborami, mogła stać się dodatkowym argumentem dla tych, którzy gotowi byli oddać głos zmieniający układ sił na scenie politycznej (Figel, Jachowicz, 2006, s. 2).

„Nasza Ukraina” postulowała poparcie władz w rozmowach z Rosją i krytykowała zarówno Partię Regionów, jak i Julię Tymoszenko za głoszenie poglądów uważanych za antyukraińskie i wykorzystywanych propagandowo przez rosyjskie media. Opozycja (w tym Leonid Krawczuk) uważała bowiem rząd za niekompetentny i niezdolny do porozumienia z Kremlem w tej newralgicznej kwestii. Także byli członkowie bloku prezydenta sądzili, że odpowiedzią na gazowy szantaż powinna być rewizja umów dotyczących stacjonującej na Ukrainie Floty Czarnomorskiej, a władze nie dość zdecydowanie bronią interesów kraju. Janukowycz do puli zarzutów wobec Juszczenki dodawal „wysługiwanie się" Ameryce i antyrosyjską politykę, której potencjalnych skutków nie rozważono. W jego opinii ceną za poprawę dwustronnych relacji miała być zmiana postawy wobec współpracy z państwami Wspólnej Przestrzeni Gospodarczej i rezygnacja z aktywnych działań w ramach GUAAM i Wspólnoty Demokratycznego Wyboru. Julia Tymoszenko szła dalej w swoich ocenach uznając, że rząd powinien podać się do dymisji, jeśli nie wynegocjuje korzystnych dla Ukrainy rozwiązań, a Natalia Witrenko wręcz postulowała porozumienie opozycji z Rosją za plecami rządzących (Springer, 2005; Figel, Jachowicz, 2006, s. 1-2).

Kryzys w stosunkach z Rosją początkowo nie wpłynął negatywnie na postrzeganie obozu rządzącego, a wręcz przeciwnie, jego notowania wzrosły o 4 punkty procentowe.

Zdecydowana krytyka była silniejsza wśród oponentów politycznych „Naszej Ukrainy” niż społeczeństwa, które, jak można wnioskować, winą za zaistniałą sytuację w znaczniej mierze obarczało Rosję (Figel, Jachowicz, 2006, s. 2). Jednakże 4 lutego 2006 r. na łamach tygodnika „Zierkało nedieli” („Зеркало недели”) opublikowano artykuł na temat niejawnych umów zawartych pomiędzy Naftohazem Ukrainy i Gazpromem, które stanowiły 
poważne zagrożenie dla kontroli Kijowa nad sytuacją energetyczną w kraju. Naftohaz, godząc się na magazynowanie przez RosUkrEnergo gazu po symbolicznych wręcz stawkach, narażał się na potężne straty finansowe, pozbawiał się też możliwości sprawnego działania „w sytuacji niespodziewanego, okresowego wzrostu zapotrzebowania”. Co więcej, RosUkrEnergo miałoby przejąć kontrolę nad dostawami na Ukrainę gazu z Turkmenistanu i innych państw Azji Centralnej, a docelowo dyktowałoby ceny odbiorcom przemysłowym. Wpływałoby tym samym na wzrost cen dla odbiorców indywidualnych, co doprowadziłoby do „rozkwitu patologicznych zjawisk z pogranicza gospodarki i polityki”, przede wszystkim do umocnienia prorosyjskich ugrupowań na Ukrainie. Ukrhaz zostałby zredukowany do roli wykonawcy dyrektyw Gazpromu, który decydowałby w sprawach ukraińskiego rynku gazowego, ale nie musiałby na nim sprzedawać swojego surowca.

Jak zaznaczano w notatce Ambasady RP, jeśli pakiet takich umów rzeczywiście istniał, to jego ujawnienie wpłynęłoby na osłabienie pozycji Juszczenki, kontynuującego schematy wypracowane przez jego poprzednika, Leonida Kuczmę. Doprowadziłoby to do rozbicia pomarańczowych wzmacniając Tymoszenko. Postawiłoby też Ukrainę w negatywnym świetle na arenie międzynarodowej i odsunęło ją od integracji euroatlantyckiej (Zajączkowski, 2006, s. 1-2).

Pomimo rozwiązania spornych kwestii i zawarcia porozumienia międzypaństwowego w sprawie cen i zasad dostaw gazu na Ukrainę na okres pięciu lat, o czym poinformowano 4 stycznia 2006 r., sytuacja ta ukazała skalę rozłamu w obozie rządzącym. Dla opozycji, ale też dawnych sojuszników Juszczenki, była to okazja do osłabienia pozycji prezydenta i rządu, co mogło spotkać się z aprobatą Rosji. Zarazem, jak można przypuszczać, rozczarowaniem dla Moskwy mógł być brak woli zbliżenia z Kremlem ze strony ukraińskiej opozycji. Podczas konfliktu skupiła ona swą uwagę na wewnętrznych rozgrywkach politycznych, pozostając (przynajmniej formalnie) negatywnie usposobioną do rosyjskich postulatów czy nawet samego porozumienia. Wydaje się, że ostrożność ta wynikała ze świadomości tego, iż otwarte okazywanie sympatii wobec Rosji będzie politycznym samobójstwem. 


\section{Monitoring}

Wybory do Rady Najwyższej, zgodnie z ustaleniami Centralnej Komisji Wyborczej Ukrainy, miały być „w pełni demokratyczne”, czemu miały służyć m.in. zgody na otrzymanie statusu obserwatora dla członków organizacji pozarządowych, zmiany prawne ograniczające możliwość fałszowania wyników wyborów przez członków komisji wyborczych czy ograniczenie bezprawnego wpływu ugrupowań partyjnych i administracji na przebieg kampanii. Aby zagwarantować odpowiedni monitoring głosowania prezydent Juszczenko zaprosił społeczność międzynarodową do obserwacji całego procesu. Jak zapowiedział minister spraw zagranicznych Borys Tarasiuk, wyłączeni z tego procesu mieli być jedynie obywatele WNP, ze względu na „brak międzynarodowego uznania tej struktury za organizację" (Kowalczuk, 2006, s. 1).

Łącznie zarejestrowano 3516 obserwatorów międzynarodowych, wśród nich ok. 2100 organizacji pozarządowych. Grono obserwatorów z Polski liczyło 455 osób, z czego 46 występowało z ramienia OBWE. Z kolei delegacja polskiej misji dyplomatycznej obserwowała przebieg głosowania w miejscowościach Donieck, Starobeszewe, Kutejnikowe, Amwrosijiwka, Tores, Zugres, Makijiwka oraz na Krymie: w Symferopolu, Sewastopolu, Ałuszcie i Gruzufie, a Ambasada RP w Kijowie organizowała spotkania poświęcone sytuacji wewnętrznej na Ukrainie czy sposobom prowadzenia monitoringu (Kowalczuk, 2006, s. 2).

Jak oceniano, wybory przebiegały bez zakłóceń. Obserwujący je w Kołomyi w obwodzie iwano-frankowskim Rafał Poborski stwierdził, że w dniu głosowania komitety wyborcze nie wykazywały żadnej aktywności, a obywatele mieli sprecyzowane poglądy na temat kandydatów. Ponadto akcentowali wagę wyników wyborów samorządowych (do władz regionalnych, miejskich, wiejskich i gromadzkich), które odbywały się równolegle z wyborami parlamentarnymi (Zajączkowski, 2006, s. 4).

Czynności wykonywane przez komisje wyborcze były zgodne z wymogami i przepisami ordynacji wyborczej, wskazywano na sprawność zespołów mobilnych, których zadaniem było zapewnienie możliwości głosowania w domach osobom do tego uprawnionym. Jako pozbawione wpływu na cały proces wyborczy oceniano natomiast błędy w spisach wyborczych (nieprawidłowy zapis nazwisk, literówki), które korygowano na bieżąco, 
bez uprzedniej decyzji sądu. Był to problem nienowy, borykano się z nim już podczas wyborów 2004 r. Jednostkowe były również przypadki nieumieszczenia na listach wyborców uprawnionych do głosowania. Wysoka frekwencja przełożyła się natomiast na problemy logistyczne i widoczne zmęczenie członków komisji oraz kolejki w lokalach wyborczych. Te były potęgowane przez wielkość kart wyborczych, których długość sięgała 75 centymetrów i utrudniała szybką orientację w treści, co niekiedy wręcz zniechęcało do głosowania. Proces liczenia głosów wydłużały z kolei nieliczne przypadki braku pełnego składu komisji, które, w opinii Polaków, nie wpływały na ich pracę w zasadniczy sposób. Wszelkie błędy, zdaniem obserwatorów OBWE, nie były próbą fałszowania wyników (Kowalczuk, 2006, s. 2-3; Zajączkowski, 2006, s. 1-4).

W odróżnieniu od wyborów z 2004 r. w lokalach sporadycznie spotykano funkcjonariuszy milicji podczas służby. Miało to miejsce na przykład w obwodzie lwowskim, gdzie nie ingerowali oni jednak w przebieg głosowania, lecz pilnowali porządku (Zajączkowski, 2006, s. 5). Komisje skrupulatnie przestrzegały procedur, pracowały w sposób transparentny i bez nacisków osób trzecich. Podkreślano dużą liczbę obserwatorów, głównie młodych, oraz osób prowadzących badania exit poll, choć nie cieszyły się one zaufaniem średniego i starszego pokolenia, które niechętnie odpowiadało na pytania ankieterów. Ostatecznie wybory obserwowały trzy grupy obserwatorów: z ramienia partii i bloków, państw i organizacji międzynarodowych oraz organizacji społecznych, co było novum w ukraińskich realiach. Spośród szesnastu organizacji pozarządowych zarejestrowanych w 225 okręgach wyborczych siedem miało charakter ogólnokrajowy, przy czym ich udział określano jako minimalny: „dominowali przedstawiciele partii i bloków”. Przeciętnie na jeden punkt, w którym oddawano głosy, przypadało około dwudziestu obserwatorów reprezentujących różne opcje polityczne, choć mogło ich być nawet dwukrotnie więcej. Mniejsza natomiast, niż w wyborach prezydenckich, była liczba obserwatorów międzynarodowych, co sprawiło że w wielu lokalach nie byli oni obecni (Zajączkowski, 2006, s. 3$)^{5}$.

5 Charakter ogólnokrajowy miały następujące organizacje pozarządowe: Komitet Wyborców Ukrainy, Instytut Prawa Wyborczego, Federacja Związków Zawodowych, Obrońcy Ukrainy, Nowa Generacja, Ukraiński Związek Weteranów Afganistanu, organizacja kobieca „Solidarność”. 


\section{Wyniki wyborów}

W głosowaniu, które trwało od godz. 7.00 do 22.00, wzięło udział 67,13 proc. uprawnionych wyborców. Najwyższą frekwencję, bo sięgającą nawet ok. 76 proc., odnotowano w zachodnich obwodach kraju. Niższą, ok. 63-68 proc., wskazywano we wschodnich i południowych obwodach i na Krymie (Zajączkowski, 2006, s. 1; Zajączkowski, 2006, s. 1).

Tabela 5. Rezultaty wyborów do Rady Najwyższej Ukrainy w 2006 r.

\begin{tabular}{|l|l|l|}
\hline Partia/blok & $\begin{array}{l}\text { Procentowy wynik } \\
\text { wyborów }\end{array}$ & $\begin{array}{l}\text { Liczba zdobytych } \\
\text { mandatów }\end{array}$ \\
\hline Partia Regionów & 32,14 & 186 \\
\hline Blok Julii Tymoszenko & 22,29 & 129 \\
\hline Blok „Nasza Ukraina” & 13,95 & 81 \\
\hline Socjalistyczna Partia Ukrainy & 5,69 & 33 \\
\hline Komunistyczna Partia Ukrainy & 3,66 & 21 \\
\hline
\end{tabular}

Źródło: Вибори..., 2006; Вісник Центральної виборчої комісії 2007, nr 1, s. 95; Notatka..., 2006, s. 4.

Dane CKW, ogłoszone 30 marca 2006 r., wskazywały że największym poparciem obywateli cieszyła się Partia Regionów, która zdobyła 32,14 proc. głosów. Blisko o 10 proc. niższe było poparcie dla Bloku Julii Tymoszenko (22,29 proc.). Za nim uplasowała się „Nasza Ukraina”, na którą głosowało 13,95 proc. wyborców. W parlamencie znalazły się jeszcze cztery ugrupowania, lecz żadne z nich nie osiągnęło dwucyfrowego rezultatu w wyborach: Socjalistyczna Partia Ukrainy (5,69 proc.), Komunistyczna Partia Ukrainy (3,66 proc.), Blok Natalii Witrenko (2,93 proc.) i Ludowy Blok Wołodymyra Łytwyna (2,44 proc.). Pozostałe ugrupowania nie przekroczyły progu wyborczego (Вибори..., 2006) ${ }^{6}$. Małe poparcie, jakim cieszyły się partie prezentujące radykalne poglądy, prawicowe, antynatowskie czy prorosyjskie (jak Blok Natalii Witrenko, Blok Łytwyna czy Partia Pora, czy też Partii Polityki Putina)

6 Blok Natalii Witrenko „Ludowa Opozycja” otrzymał 2,93 proc. głosów, Ludowy Blok Łytwyna 2,44 proc., Ukraiński Ludowy Blok Kostenki i Pluszcza 1,87 proc., Wicze 1,74 proc., Blok Pora-PRP 1,47 proc., Opozycyjny Blok Nie Tak 1,01 proc. Inne ugrupowania łącznie zdobyły nieco ponad 7 proc. głosów. Głosów nieważnych oddano 1,93 proc. 
i znikomy odsetek oddanych na nie głosów wskazywały, że pozyskały one wyborców na szczeblu lokalnym, prawdopodobnie dzięki zauważalnej tam działalności, lecz nie miały szans na sukcesy ogólnokrajowe. Co za tym idzie wydawało się, że Ukraińcy wciąż skłonni są poszukiwać dróg kompromisu, a skrajne koncepcje polityków nie budzą ich zaufania.

To, w jakich obwodach poszczególne partie i bloki cieszyły się największą popularnością, ilustruje poniższe zestawienie:

Tabela 6. Rezultaty wyborów do Rady Najwyższej Ukrainy w 2006 r. - zwycięstwa ugrupowań politycznych w obwodach

\begin{tabular}{|l|l|c|}
\hline Partia/blok & Obwód & Procent zdobytych głosów \\
\hline Partia Regionów & Obwód łuhański & 74,3 \\
\hline Blok Julii Tymoszenko & Obwód kijowski & 44,5 \\
\hline Blok „Nasza Ukraina” & Obwód iwano-frankowski & 45,0 \\
\hline Socjalistyczna Partia Ukrainy & Obwód winnicki & 14,6 \\
\hline Komunistyczna Partia Ukrainy & Obwód chersoński & 6,8 \\
\hline
\end{tabular}

Źródło: Buбори..., 2006; Notatka..., 2006, s. 4.

Członkowie Bloku Łytwyna, ugrupowania Witrenko, Kostenki i Pluszcza czy „Nie Tak!” byli zaskoczeni tym, że nie udało im się przekroczyć progu wyborczego i zamierzali żądać ponownego przeliczenia głosów („przynajmniej w niektórych obwodach").W kilku miejscowościach, w tym na Krymie, przed siedzibami komisji wyborczych zorganizowano protesty, sugerowano też istnienie zamierzonych błędów w protokołach, a wszelkie uwagi Centralna Komisja Wyborcza rozpatrywała na bieżąco (Kowalczuk, 2006, s. 2-3; Zajączkowski, 2006, s. 1; Zajączkowski, 2006, s. 2-4).

Partia Regionów zwyciężyła, poza obwodem łuhańskim, w obwodach donieckim (73,6 proc.), dniepropietrowskim (45 proc.), zaporoskim (51,2 proc.), mikołajewskim (50,4 proc.), odeskim (47,5 proc.), charkowskim (51,7 proc.), chersońskim (39,1 proc.), w Sewastopolu (64,3 proc.) oraz na Krymie (57,9 proc.). Na zachodzie kraju tylko w niektórych miejscowościach, jak w Czerwonohradzie, „górniczym mieście zamieszkiwanym przez rosyjską mniejszość” i jego najbliższych okolicach, dało się zauważyć stosunkowo duże poparcie dla Partii Regionów, przekraczające niekiedy 10 proc. głosów. Jednakże i tam bezapelacyjnie przewagę miały „Nasza Ukraina” i BJuT, niemniej przypadek wspomnianych miejscowości wskazuje na pojawiającą się zależność pomiędzy 
przynależnością etniczną a preferencjami wyborczymi. Akcentowanie przez ugrupowanie Janukowycza kwestii istotnych dla mniejszości rosyjskiej wpływało na jego popularność nie tylko we wschodnich czy południowych obwodach kraju, ale też w enklawach zamieszkiwanych przez znaczny odsetek tej społeczności w zachodnich obwodach, postrzeganych jako nieprzychylne zbliżeniu z Moskwą, za to proeuropejskie (Zajączkowski, 2006, s. 5) ${ }^{7}$.

BJuT cieszył się największym poparciem w obwodach winnickim (33,2 proc.), wołyńskim (43,9 proc.), żytomierskim (24,9 proc.), kirowohradzkim (30,1 proc.), połtawskim (26,8 proc.), rówieńskim (31,3 proc.), sumskim (33,2 proc.), tarnopolskim (34,5 proc.), chmielnickim (35,6 proc.), czerkaskim (38,2 proc.), czerniowieckim (33,8 proc.) oraz w Kijowie (39,2 proc.). Natomiast „Nasza Ukraina” największą przewagę nad konkurentami miała w obwodzie zakarpackim (25,8 proc.) i lwowskim (37,9 proc.) (Вибори..., 2006). W porównaniu z Blokiem Julii Tymoszenko zdecydowanie traciła na popularności, a tym samym malało jej znaczenie na scenie politycznej, w coraz mniejszym stopniu była też utożsamiana $z$ ideami pomarańczowej rewolucji. Należy przypomnieć, że w wyborach parlamentarnych 2002 r. przewaga NU nad BJuT była znacząca. Ugrupowanie to otrzymało wówczas 23,57 proc. głosów, podczas gdy Blok zaledwie 7,26 proc. (Підсумки...; Zajączkowski, 2006, s. 5) ${ }^{8}$.

Istotną rolę w tej sytuacji mogła odegrać Socjalistyczna Partia Ukrainy, bez której, jak oceniała Ambasada RP w Kijowie, niemożliwe byłoby stworzenie pomarańczowej koalicji partyjnej. SPU osiągnęła co prawda wynik nieco niższy niż w wyborach 2002 r. (zdobyła wówczas 6,87 proc. głosów), prawdopodobnie w dużej mierze dlatego, że część jej elektoratu przejął BJuT. Sojusz z socjalistami był dla polityków jednak wciąż o tyle ważny, że próba utworzenia aliansu „Naszej Ukrainy” i Partii Regionów nie tylko mogła

7 Partia Regionów w wyborach 2002 r. startowała w ramach bloku „Za Jedyną Ukrainę”, który uzyskał trzeci rezultat, 11,77 proc., po Komunistycznej Partii Ukrainy, która dostała 19,98 proc. głosów.

8 W obwodzie lwowskim, gdzie obserwatorem był m.in. Marcin Zochowski, kampanię zdominowały plakaty zachęcające do głosowania na „Naszą Ukrainę”, ale końcowym akcentem był wiec Julii Tymoszenko połączony z koncertem „popularnych grup muzycznych". Impreza ta nie wpłynęła na preferencje wyborców i ugrupowanie Juszczenki wygrało w obwodzie, zdobywając 37,94 proc. poparcia. 
okazać się przedsięwzięciem karkołomnym, ale też oceniano, że ostatecznie pogrążyłaby Juszczenkę jako polityka niewiarygodnego i lawirującego pomiędzy skrajnymi poglądami (Підсумки...).

Sukcesu nie osiągnęła Komunistyczna Partia Ukrainy, która w 2002 r. zajęła drugie miejsce w wyborach, zdobywając 19,98 proc. głosów. Spadek poparcia do zaledwie 3,7 proc. można było uznać za wyborczą porażkę. Zmiany kadrowe i położenie nacisku na hasła populistyczne, w miejsce tradycyjnie lewicowych postulatów, nie zaskarbiły jej sympatii, a mogły spowodować odpływ konserwatywnych sympatyków. Przykład Bloku Łytwyna, który usiłował zagospodarować polityczne centrum i pogodzić przeciwstawne poglądy polityczne oraz stać się atrakcyjnym zarówno dla mieszkańców wschodu, jak i zachodu kraju, wskazywał że Ukraińcy preferowali ugrupowania o bardziej wyrazistych poglądach. Zarazem aplauzu nie budziły postulaty, takie jak Bloku Natalii Witrenko, który nie przekroczył progu wyborczego. Zerwanie umowy z Międzynarodowym Funduszem Walutowym, strategiczne partnerstwo z Rosją i Białorusią oraz trójstronny sojusz z tymi państwami mogły dla wielu Ukraińców okazać się zbyt daleko idącymi hasłami (Виборчий блок...).

\section{Koalicja}

Mimo wygranej partii Janukowycza wydawało się, że zarazem będzie ona wielką przegraną, gdyż wszystko wskazywało na to, że to połączone siły ugrupowań „pomarańczowych” przejmą władzę na Ukrainie. Spośród 450 mandatów w Radzie Najwyższej 129 przypadło w udziale BJuT, 81 Blokowi wyborczemu „Nasza Ukraina”, 33 SPU. Łącznie „pomarańczowi” mogli wprowadzić do parlamentu 243 deputowanych, Partia Regionów - 186 (Протокол..., 2006).

Jak zauważyła Ambasada RP w Kijowie, wyniki głosowania do pewnego stopnia były zaskoczeniem. Prezydent Juszczenko co prawda spodziewał się zwycięstwa Partii Regionów, prognozowanego w sondażach, natomiast nie liczył się z tak dużą przewagą BJuT nad „Naszą Ukrainą”. Ugrupowanie Tymoszenko chciało ten fakt wykorzystać, zapowiadając podpisanie 27 marca 2006 r., o godz. 11.00, umowy koalicyjnej z "Naszą Ukrainą” i SPU, lecz ostatecznie decyzja ta została odroczona (Zajączkowski, 2006, s. 3). 
Rozmowy na ten temat szefowie sztabów wyborczych oraz kampanii prowadzonych przez BJuT, „Naszą Ukrainę” i Socjalistyczną Partię Ukrainy prowadzili już oczekując na rezultaty głosowania „w noc wyborczą”. Przyjęto wówczas, że kandydata na premiera wyznaczy to z ugrupowań, które zdobędzie największe poparcie obywateli. Jak się jednak wydawało, decyzja niosłaby za sobą problemy wobec rozbieżności w koncepcjach realizacji polityki zagranicznej i wewnętrznej, cechujących poszczególnych kandydatów. Spodziewano się, że gdyby szefem rządu została Julia Tymoszenko zdecydowałaby się na wprowadzanie elementów centralnego sterowania gospodarką, co spotkałoby się prawdopodobnie z krytyką innych ugrupowań. Ponadto do podziałów w łonie koalicji prowadziłaby kwestia renegocjacji umów gazowych z Rosją, za czym optowała BJuT. NU przeciwnie, sądziła że należało dopracować te, które już zostały zawarte. Politycy mieli być natomiast zgodni w kwestii potencjalnego wejścia Ukrainy do NATO, co miało być celem dla wszystkich ugrupowań (Zajączkowski, 2006, s. 2-3).

Koalicja „Naszej Ukrainy” z BJuT i SPU byłaby oczekiwanym przez wyborców tych ugrupowań porozumieniem sił obozu pomarańczowych, mogącym pozytywnie wpłynąć na jego popularność. Zdolność do porozumienia się Juszczenki i Tymoszenko przełożyłaby się na poprawę wizerunku przede wszystkim prezydenta, podczas gdy próba budowy sojuszu z dotychczasowym przeciwnikiem byłaby dla niego niewątpliwie klęską wizerunkową. Tymczasem odłożenie w czasie utworzenia „pomarańczowej koalicji” wskazywało, że Juszczenko (wyraźnie przeciwny temu, by jego ugrupowanie było postrzegane jako zależne od partii Tymoszenko) mógł zdecydować się na alians z Partią Regionów, byle nie zajmować pozycji drugoplanowej w przyszłym sojuszu.

Nawet, jeśli mowa tu była o przymierzu między Partią Regionów i „Naszą Ukrainą” nie tyle formalnym, co raczej celem wsparcia dla „rządu technicznego", to zwrot taki mógł być ryzykowny dla Juszczenki i spowodować dalszy spadek poparcia dla prezydenta i jego bloku. Nie należało się bowiem spodziewać przejęcia elektoratu Janukowycza; rozbieżności pomiędzy obu politykami były zbyt duże. Zwolennicy prozachodniej drogi Ukrainy mogli potraktować współpracę z PR w kategoriach zdrady i przenieść swoje poparcie na partię Julii Tymoszenko, co zademonstrowano już podczas wyborów 
oddając na BJuT niemal 9 proc. głosów więcej, niż na prezydencką „Naszą Ukrainę".

Można zauważyć, że na największe poparcie dla zbliżenia z Partią Regionów można było liczyć wśród środowiska biznesowego związanego z „Naszą Ukrainą", które nieprzychylnie odnosiło się do potencjalnego objęcia fotela premiera przez Tymoszenko; m.in. Petro Poroszenko, Ołeksandr Trietiakow i Mykoła Martynenko zabiegali o pozyskanie zwolenników dla takiej koncepcji, lecz inni członkowie bloku nie byli jej przychylni. Jednocześnie NU zdecydowała się promować na stanowisko przewodniczącego parlamentu Poroszenkę, co również było posunięciem ryzykownym. Były sekretarz Rady Bezpieczeństwa i Obrony, skonfliktowany z Tymoszenko, oskarżony o korupcję i w sprawie karnej, był osobą niewątpliwie kontrowersyjną (Лещенко, 2014).

Niemniej grupa przedsiębiorców zyskiwała, jak się wydaje, coraz większe wpływy. 13 czerwca 2006 r. Rada Programowa NU zadecydowała o możliwości stworzenia koalicji demokratycznej wraz z Partią Regionów. Dwa dni później do wiadomości publicznej podano informację o decyzji Janukowycza, w myśl której możliwe było przyjęcie warunków koalicjantów. Nie były to jednak wciąż decyzje wiążące (Notatka...,2006, s. 2-3; Партія Регіонів...). Stawką w grze było, zgodnie z nową ordynacją wyborczą, obsadzenie stanowiska premiera, który, odpowiadając za politykę wewnętrzną de facto stawał się osobą ważniejszą od prezydenta.

Wciąż jednak wydawało się, że prezydent nie miał pewności, że „Naszej Ukrainie" uda się przeforsować swojego kandydata we współpracy z PR. BJuT mógł być bardziej przewidywalnym koalicjantem szczególnie, że groźba utraty wpływów skłoniła Tymoszenko do poszukiwania drogi do porozumienia. Ponownie podjęto rozmowy, po czym zaakceptowano kandydaturę Poroszenki na stanowisko spikera. Choć część deputowanych NU („Siedemnaście osób, głównie biznesmeni”) występowała przeciw potencjalnemu objęciu funkcji premiera przez Tymoszenko, to możliwość przyznania tego urzędu Poroszence odrzucono. Pierwszym wiceprzewodniczącym Rady Najwyższej miał zostać członek SPU Josip Wiński.

Przyjęcie umowy zostało odebrane przez PR i KPU z pewną nerwowością - politycy dostrzegali zagrożenie utrwaleniem porozumienia między „pomarańczowymi”. Zdaniem Petra Symonenki była to próba ponownego „przejęcia 
władzy przez ludzi skorumpowanych", która umocni antagonizmy wewnątrz kraju. Decyzja o powołaniu koalicji została wcielona w życie 22 czerwca 2006 r. 239 deputowanych (z 243 należących do frakcji koalicyjnych) złożyło podpisy pod stosowną umową, a Roman Bezsmertny, Ołeksandr Moroz i Julia Tymoszenko ogłosili jej treść. Zgodnie z ustaleniami BJuT miał otrzymać stanowisko premiera, wicepremiera miała desygnować „Nasza Ukraina”, a pierwszego wicepremiera Socjalistyczna Partia Ukrainy. Odpowiednio ugrupowania te otrzymały dziesięć, sześć (lub pięć) i trzy teki ministerialne. Dla przedstawicieli opozycji przewidziano stanowiska pierwszych zastępców przewodniczących wszystkich komisji parlamentarnych oraz przewodniczącego Komisji Kontrolnej ds. Prywatyzacji. Faktycznie BJuT przejął kontrolę nad resortami związanymi z gospodarką, Naftogazem Ukrainy, Funduszem Mienia Państwowego i Państwowym Komitetem ds. Radiofonii i Telewizji, Administracją Podatkową oraz Skarbem Państwa (Тексm коаліційної..., 2006; Figiel, 2006, s. 1-2).

Choć negocjacje trwały blisko trzy miesiące, to politycy nie naruszyli terminów wskazanych w ustawie zasadniczej. Mimo to trudności w osiągnięciu porozumienia mogły źle wróżyć stabilizacji sceny politycznej. Szczególnie problematyczna mogła się okazać nominacja na przewodniczącego Rady Najwyższej Poroszenki, który przodował w rankingach „na najbardziej niepopularną postać polityczną". Miał on zrównoważyć wpływy Tymoszenko, ale niechęć jaką żywiła do niego znaczna część obozu pomarańczowych wskazywała, że to właśnie kontrowersje personalne, a nie spór o kształt polityki państwa, mogą położyć się cieniem na przyszłej współpracy. Dowodzić tego miał fakt, że dyskusja na temat umowy koalicyjnej toczyła się nadal, mimo iż dokument ten został już przygotowany (Notatka..., 2006, s. 5).

Wobec kontrowersji względem kolejnych nominacji, szczególnie dotyczących kandydatów wywodzących się ze środowisk biznesowych, obawiano się, że porozumienie nie będzie trwałe, a niektórzy z deputowanych mogą przejść na stronę opozycji. Ze względu na deklaracje składane przez Tymoszenko, która jako premier chciała dokonać przeglądu umów na dostawy surowców energetycznych, było też niewygodne dla Rosji i przypuszczano, że Moskwa dołoży zakulisowych starań, by ideę tę storpedować. Szans na utrzymanie jedności obozu pomarańczowych nie widziała m.in. Partia Regionów, która, jako zwycięzca wyborów, uważała że to jej członkom powinny przypaść 
stanowiska premiera i wicepremiera oraz blok ekonomiczny w rządzie (który objąć miał BJuT). Przedłużające się negocjacje i kontrowersje narastające wokół Poroszenki, przejęcie przez koalicjantów stanowisk przewodniczących komitetów parlamentarnych oraz plany jednoczesnego i jawnego głosowania kandydatur premiera i spikera Rady Najwyższej wpłynęły na radykalizację działań PR. Nie chcąc dopuścić do tego, by zmiany w regulaminie Rady Najwyższej utwierdziły przewagę „pomarańczowych”, Partia Regionów zdecydowała się na blokadę trybuny parlamentarnej rozpoczętą 27 czerwca 2006 r.

Porozumienie udało się osiągnąć dopiero 6 lipca, kiedy to opozycja zyskała prawo przewodniczenia kilkunastu komitetom oraz zapewnienie o rezygnacji $z$ „głosowania pakietem na premiera i przewodniczącego parlamentu". Tego samego dnia nastąpiła też zasadnicza zmiana w układzie sił politycznych. SPU odwróciła się od dotychczasowych sprzymierzeńców i wraz z Partią Regionów i KPU stworzyła nową większość parlamentarną, wysuwając zarazem kandydaturę Ołeksandra Moroza na stanowisko przewodniczącego Rady Najwyższej. Zwrot w polityce prowadzonej przez SPU unaocznił skalę problemów i konfliktów, jakie zdominowały sytuację wewnętrzną w kraju, a ceną dla PR i KPU, jaką przyszło zapłacić za porozumienie, było stuprocentowe poparcie dla Moroza, mimo iż partia Janukowycza proponowała na spikera Mykołę Azarowa. Poroszenko wycofał się z walki o urząd, a nowa „koalicja antykryzysowa” zgodnie poparła Moroza, po czym na stanowisko premiera wysunęła kandydaturę Wiktora Janukowycza. BJuT oficjalnie ogłosił przejście na stronę opozycji (Figiel, 2006, s. 1; Notatka..., 2006, s. 5-6; Figiel, 2006, s. 1).

Tym samym inicjatywa utworzenia koalicji rządzącej spoczęła w rękach Partii Regionów, Komunistycznej Partii Ukrainy i Socjalistycznej Partii Ukrainy. 7 lipca liderzy ugrupowań, Wiktor Janukowycz, Petro Symonenko i Wasyl Cuszko podpisali ugodę w sprawie utworzenia koalicji. 8 lipca 2006 r. Juszczenko, wygłaszając przemówienie radiowe, „dał do zrozumienia” że gotów jest zaaprobować kandydaturę Janukowycza na premiera pod warunkiem, że deputowani zatwierdzą skład Sądu Konstytucyjnego (Notatka..., 2006, s. 2-3; Партія Регіонів...).

Jeśli przyjąć, że ogromną rolę w poczynaniach polityków odgrywały wówczas sympatie i antypatie osobiste, to zwrot ten był niewątpliwie korzystny 
dla Juszczenki, który nie aprobował powrotu Julii Tymoszenko na stanowisko premiera i pozostawał w jej cieniu. Jednocześnie wydawało się, że prezydent mógł liczyć na to, że nie uda się powołać rządu, a tym samym po 25 lipca będzie mógł skorzystać z ustawowego prawa do rozwiązania parlamentu i rozpisać przedterminowe wybory. Krok taki oceniano jednakże jako ryzykowny, mogący ugruntować przewagę PR i BJuT. „Nasza Ukraina” prawdopodobnie zdobyłaby w ponownym głosowaniu mniej mandatów niż uprzednio, co wynikałoby z rozczarowania polityką prowadzoną przez prezydenta oraz powyborczymi przetasowaniami w parlamencie.

Z kolei zatwierdzenie tzw. koalicji antykryzysowej, złożonej z przedstawicieli klanu donieckiego, komunistów i socjalistów, niosło ryzyko przejęcia przez nią kolejnych posłów opozycji, którą tworzyłyby NU i BJuT. Było to o tyle prawdopodobne, że koalicja ta „przyjęła za porozumienie programowe" umowę przygotowaną przez „pomarańczowych”, dając tym sygnał, iż jej celem nie jest tworzenie sytuacji konfrontacyjnych. Potencjalne porozumienie NU i PR uzależnione było, zdaniem ukraińskich komentatorów, od wystąpienia z koalicji komunistów i rezygnacji Janukowycza z kandydowania na stanowisko premiera (Notatka..., 2006, s. 6).

Niewątpliwie Partia Regionów umiejętnie wykorzystała słabość i konflikty wśród „pomarańczowych”, w tym ten związany z osobą Petra Poroszenki. Kolejne kroki polityków zależeć miały od zdolności do kompromisu pomiędzy PR i NU. W przypadku jego braku przejście NU do opozycji lub ponowne połączenie sił z BJuT pogłębiłoby kryzys polityczny i podziały wewnątrz państwa. Okrojenie liczby ugrupowań, które znalazły się w parlamencie, wymuszało nawiązanie przez nie współpracy i podjęcie rozmów, umożliwiających skuteczną realizację polityki. Niewątpliwie przychylność prezydenta mogła mieć duże znaczenie dla działań planowanych przez otoczenie Janukowycza, a utrudniać je mogły powiązania ze środowiskami biznesowymi. Ugruntowanie obecności oligarchów wśród rządzących miało na kolejne lata określić kształt ukraińskich rządów.

\section{Powołanie rządu}

Początkowo Juszczenko powstrzymywał się, w ramach terminów konstytucyjnych, z powzięciem decyzji w sprawie nominacji nowego szefa rządu, 
choć oficjalnie wyrażał gotowość do współpracy z przyszłym premierem. Jednocześnie prezydent chciał wynegocjować pozostawienie w rękach polityków „Naszej Ukrainy” stanowisk ministrów spraw zagranicznych, obrony, resortów spraw wewnętrznych, sprawiedliwości i służby bezpieczeństwa oraz funkcji spikera parlamentu (po usunięciu z niej Moroza). Naciski na prezydenta i deputowanych chciała też wywrzeć Julia Tymoszenko, postulująca rozwiązanie parlamentu. Aby do niego doprowadzić poszukiwała osób gotowych złożyć mandaty poselskie - 151 takich oświadczeń zobowiązałoby Juszczenkę do rozwiązania Rady Najwyższej; frakcja BJuT liczyła sobie 125 osób.

25 lipca parlament uchylił decyzję o zdymisjonowaniu rządu Jechanurowa, co miało zdaniem deputowanych, uniemożliwić prezydentowi rozwiązanie Rady Najwyższej „pod pretekstem niepowołania parlamentu”. Opcja ta nie miała zresztą wielu zwolenników wśród „Naszej Ukrainy”, gdzie większość parlamentarzystów gotowa była do porozumienia z Partią Regionów. Jak można przypuszczać, priorytetem było dla nich zachowanie stanowisk i perspektywa ponownych wyborów była trudna do zaakceptowania. Jak twierdzili „ukraińscy komentatorzy”, w tej sytuacji negocjacje z PR mogły zakończyć się sukcesem, jeśli udałoby się uzgodnić innego niż Janukowycz kandydata na stanowisko premiera. Niemniej ani Arsenij Jaceniuk, ani należący do PR Andrij Klujew czy Mykoła Azarow nie mieli na tyle silnej pozycji, aby zastąpić lidera ugrupowania (Zajączkowski, 2006, s. 1).

Kompromisowym rozwiązaniem wydawało się być przyjęcie „Uniwersału jedności narodowej”, mającego wyznaczyć kierunki narodowego rozwoju. Podpisali go Wiktor Juszczenko, Jurij Jechanurow, Ołeksandr Moroz, Roman Bezsmertnyj, Wasyl Cuszko, Wiktor Janukowycz oraz, z zastrzeżeniami, Petro Symonenko. W treści dokumentu skupiono uwagę na kwestiach językowych potwierdzając, że językiem urzędowym jest ukraiński, ale każdy obywatel ma prawo korzystać $\mathrm{z}$ innego języka ojczystego, w tym rosyjskiego. Zaznaczono również, że kwestia potencjalnego członkostwa w NATO może zostać rozwiązana na drodze referendum, rozpisanego po spełnieniu przez Kijów niezbędnych ku temu warunków. Współpraca z Paktem miała być realizowana na podstawie ustawy „O podstawach bezpieczeństwa narodowego Ukrainy”. Tym samym politycy odsuwali w czasie przyjęcie wiążących deklaracji, co więcej, przerzucali w pewien sposób odpowiedzialność za nie 
na społeczeństwo. Kontynuowana miała być też współpraca z Unią Europejską, w perspektywie prowadząca do wejścia w jej struktury. Zadeklarowano również zwiększenie bezpieczeństwa energetycznego państwa, m.in. poprzez zwiększenie efektywności wykorzystania zasobów naturalnych i wprowadzenie energooszczędnych technologii (Універсал..., 2006; Партія Регіонів...).

Uniwersał podpisany został 3 sierpnia 2006 r. Tego samego dnia Juszczenko złożył w parlamencie wniosek o powołanie na stanowisko premiera Wiktora Janukowycza, a kandydaturę tę Rada Najwyższa zaaprobowała dzień później. Liderem frakcji Partii Regionów i koordynatorem większości parlamentarnej została Raisa Bohatyrowa (Партія Регіонів...).

Wiktor Janukowycz otrzymał 271 głosów, w tym wszystkich posłów Partii Regionów i Komunistycznej Partii Ukrainy, 30 z 33 deputowanych Socjalistycznej Partii Ukrainy, 30 posłów Naszej Ukrainy i sześciu z Bloku Julii Tymoszenko. Zastępcami nowego premiera zostali członkowie PR. Stanowisko pierwszego wicepremiera i ministra finansów objął Mykoła Azarow, a pozostałymi wicepremierami zostali Wołodymyr Rybak, Andrij Klujew i Dmytro Tabacznyk. Partia Regionów przejęła też resorty gospodarcze, natomiast siłowe i polityczne przypadły „ludziom Juszczenki” (Zajączkowski, 2006, s. 1).

Nowy premier swoje urzędowanie zamierzał rozpocząć od wizyty w Moskwie, w dalszej dopiero kolejności miał odwiedzić Brukselę i Waszyngton, co mogło wskazywać jakimi priorytetami będzie kierował się w swojej polityce. Janukowycz podkreślał zresztą, że jego rząd „nie będzie prowokował antyrosyjskich nastrojów" i renegocjował porozumień gazowych z Moskwą (Zajączkowski, 2006, s. 2).

Pomimo wcześniejszych zapowiedzi problematyczne mogło okazać się utrzymanie kursu pronatowskiego w sytuacji, gdy SPU była krytycznie usposobiona wobec idei potencjalnego członkostwa w Sojuszu. Koalicjanci socjalistów natomiast musieli zabiegać o wypracowanie konsensusu, który nie spowodowałby kolejnej zmiany przymierzy i nie kwapili się, by podejmować decyzje sprzeczne $\mathrm{z}$ wolą deputowanych SPU. Ponieważ po wprowadzeniu na Ukrainie systemu parlamentarno-prezydenckiego to Rada Najwyższa miała decydujący głos, partie polityczne liczyły się w szczególny sposób z opiniami deputowanych, a dla tych ryzykowne było podejmowanie decyzji sprzecznych z oczekiwaniami elektoratu. Ten z kolei bądź był negatywnie 
usposobiony do członkostwa w NATO (czemu wyraz dano podczas protestów na Krymie związanych z manewrami Sea Breeze), bądź nie uważał go za sprawę szczególnie ważną dla targanego kryzysami państwa. Gdyby w lipcu 2006 r. zostało rozpisane referendum w sprawie wejścia Ukrainy do NATO „za” byłoby jedynie 16,3 proc. Ukraińców. 63,2 proc. było temu przeciwnych, 8,7 proc. nie wzięłoby udziału w głosowaniu, a 11,7 proc. nie miało w tej sprawie wyrobionego zdania (Центр Разумкова, 2015). Jednocześnie 43,4 proc. badanych sądziło, że priorytetowym kierunkiem polityki zagranicznej pozostaje dla Kijowa Rosja; 27,2 proc. wskazywało państwa Unii Europejskiej (Центр Разумкова, 2015a). W maju 2006 r. 55,3 proc. obywateli oceniało stosunki z Moskwą jako dobre, jako złe mniej, bo 37,7 proc. (Центр Разумкова, 2012).W tej sytuacji zasadne wydawało się lansowanie koncepcji państwa pozablokowego (Notatka..., 2006, s. 1-2).

W ten sposób Ukraina wciąż pozostawała w komfortowej, co nie znaczy najlepszej dla niej konfiguracji na międzynarodowej arenie. Utrzymując ekonomiczną zależność od Rosji gwarantowała sobie odsunięcie w czasie potencjalnych problemów z zabezpieczeniem energetycznym kraju, a dbając o interesy rosyjskojęzycznej mniejszości nie wywoływała potencjalnych sporów politycznych z Kremlem, żywo zainteresowanym utrzymaniem status quo. Równocześnie wysokie stanowiska zajmowane w rządzie przez osoby takie jak Borys Tarasiuk, minister spraw zagranicznych, dyplomata o wieloletnim stażu czy Anatolij Hrycenko, zwolennik współpracy z NATO, pozwalały początkowo żywić nadzieję, że Ukraina pozostanie wierna prozachodniemu kursowi.

Dopiero odwołanie 1 grudnia 2006 r. Tarasiuka ze stanowiska szefa MSZ, uznane przez „Naszą Ukrainę” za niezgodne z konstytucją, nie tylko rozpoczęło spór pomiędzy Radą Najwyższą, rządem i prezydentem, ale też mogło zachwiać wiarą w kontynuację polityki ukierunkowanej na Zachód, nie tylko na Moskwę. Ta wielowektorowość, charakterystyczna dla wcześniejszych rządów Janukowycza w latach 2002-2004, sprawiała że rząd nie potrafił stworzyć koncepcji polityki zagranicznej. Jej brak mógł być wykorzystywany przez Rosję, która mając świadomość tego, że Kijów nie posiada silnych sojuszników na arenie międzynarodowej, mogła realizować politykę wobec Ukrainy z pozycji państwa mającego w swoich rękach środki nacisku ekonomicznego, szczególnie w sektorze paliwowo-energetycznym. Mogło 
to być o tyle łatwiejsze, że pewne grupy społeczne upatrywały w Moskwie „naturalnego" partnera Ukrainy, co strona rosyjska umiejętnie podsycała. Jak informował Konsulat Generalny RP w Charkowie to dzięki wsparciu „rosyjskich nacjonal-komunistów” w Doniecku przez rok trwało miasteczko namiotowe „niebieskich”, a gros obywateli nie czuło się związanych z Ukrainą. Nie brakowało także polityków, którzy obnosili się ze swoimi prorosyjskimi sympatiami, jak były gubernator obwodu charkowskiego, Jewhen Kusznariow, „jeden z najbliższych współpracowników” Janukowycza, „identyfikowany z separatystami” i deklarujący, że bliżej mu do Moskwy niż Kijowa (Książek, 2006, s. 6-7).

\section{Podsumowanie}

Pomarańczowa rewolucja niosła ze sobą nadzieje na wprowadzenie na Ukrainie zmian systemowych, liberalizację przepisów dotyczących działalności gospodarczej, walkę z korupcją, przejrzystość w działaniach władzy, przyspieszenie procesów integracyjnych z Unią Europejską. Jednakże resentymenty radzieckie, szczególnie widoczne we wschodnich obwodach, słabość wewnętrzna Ukrainy, wymuszone polityczne przymierza, których kruchość ukazały powyborcze miesiące 2006 r., brak charyzmatycznego lidera miały z czasem zaowocować pogłębiającą się słabością państwa.

Zmiany koalicji ostatecznie zmieniły wyniki wyborów parlamentarnych 2006 r. Unaoczniły też obywatelom jak niewielki w istocie mogą mieć oni wpływ na losy własnego kraju. Ukraina stała się w pewnym sensie prywatnym folwarkiem polityków, którzy zarządzali nim nie zawsze w imię dobra państwa, a często partykularnych interesów. Sympatie i antypatie oraz troska deputowanych o zachowanie możliwości realizowania własnych interesów gospodarczych zaowocowały zakulisowymi rozmowami, w wyniku których to nie wola wyborców, a wewnętrzne ustalenia rządzących ukształtowały przyszłe losy państwa. Otworzyły też Rosji możliwość wpływania na sytuację nad Dnieprem.

Trudno jest przy tym wszystkie poczynania deputowanych, rządu i prezydenta uznać za konsekwentne. Niektóre decyzje zdawały się być podejmowane ad hoc i ukierunkowane na osiągnięcie maksymalnych korzyści, w tym przypadku zagarnięcie jak największego kawałka tortu jakim stała się władza 
na Ukrainie. Szerokie uprawnienia jakie zyskiwała „koalicja”, w tym możliwość powołania gabinetu ministrów, porównywalne z tymi jakie posiadał prezydent, były potężną motywacją do bezkompromisowej walki.

DR AGNIESZKA SAWICZ

Instytut Historii

Uniwersytet im. Adama Mickiewicza

ul. Umultowska 89d, 61-614 Poznań

agnsaw@amu.edu.pl

\section{Bibliografia}

\section{Akty prawne}

Закон України Про основи національної безпеки України. (2003). Відомості Верховної Ради України (ВВР), 39, ст. 351. Pobrane z: http://zakon5.rada.gov.ua/ laws/show/964-15.

Закон України Про внесення змін до Конституції України (2005). Відомості Верховної Ради Украӥни (ВВР), 2, ст. 44. Pobrane z: http://zakon3.rada.gov.ua/ laws/show/2222-15.

\section{Dokumenty archiwalne}

Beziuk, E. (2006, 15 marca). Notatka informacyjna nt. rankingów wyborczych partii politycznych i bloków oraz zróżnicowania regionalnego sympatii społecznych $w$ kampanii wyborczej 2006 r. na Ukrainie. Archiwum Ministerstwa Spraw Zagranicznych Rzeczpospolitej Polskiej (AMSZ), nr zespołu 180/09, w. IV, t. DW-223, t. DW-Ua-223-6-06.

Beziuk, E. (2005, 18 grudnia). Notatka informacyjna nt. pierwszych tygodni parlamentarnej kampanii wyborczej na Ukrainie. AMSZ, nr zespołu 177/09, w. IV, t. DW-Ua-223-21-05.

Beziuk, E. (2005, 7 grudnia). Notatka informacyjna nt. zjazdu wyborczego Bloku Julii Tymoszenko. AMSZ, nr zespołu 177/09, w. IV, t. DW-Ua-223-22-05.

Figiel, E. (2006, 13 czerwca). Notatka informacyjna nt. sytuacji na ukraińskiej scenie politycznej. AMSZ, nr zespołu 180/09, w. IV, t. DW-Ua-223-14-06.

Figiel, E. (2006, 23 czerwca). Notatka informacyjna nt. powołania koalicji parlamentarnej na Ukrainie. AMSZ, nr zespołu 180/09, w. IV, t. DW-Ua-223-12-06.

Figel, E., Jachowicz, K. (2006, 6 stycznia). Notatka informacyjna dot. znaczenia kryzysu gazowego dla sytuacji wewnątrzpolitycznej na Ukrainie. AMSZ, nr zespołu 180/09, w. IV, t. DW-Ua-22-1-06.

Kowalczuk, R. (2006, 4 kwietnia). Notatka na temat monitoringu wyborów do Rady Najwyższej Ukrainy przez polskich obserwatorów. AMSZ, nr zespołu 180/09, w. IV, t. DW-Ua-2221-06. 
Książek, J. (2006, 15 lutego). Notatka informacyjna dotycząca sytuacji przed wyborami w Charkowie i na wschodzie Ukrainy (styczeń-luty 2006 r.). AMSZ, nabytek nr 269/09, w. 2.

Notatka informacyjna nt. popularności idei członkostwa Ukrainy w NATO na Ukrainie. (2006, 14 lipca). AMSZ, nr zespołu 180/09, w. IV, t. DW-Ua-27-1-06.

Notatka informacyjna na temat sytuacji wewnętrznej i polityki zagranicznej Ukrainy w I kwartale 2006 r. (2006, 12 kwietnia). AMSZ, nr zespołu 180/09, wiązka IV, teczka DW-Ua-223-7-06.

Notatka informacyjna nt. sytuacji wewnętrznej i polityki zagranicznej Ukrainy w II kwartale 2006 r. (2006, 24 lipca). AMSZ, nr zespołu 180/09, w. IV, t. DW-Ua-2221-2-06.

Zajączkowski, W. (2006, 27 marca) Notatka dot. wyborów parlamentarnych na Ukrainie 26 bm., AMSZ, nr zespołu 180/09, w. IV, t. DW-Ua-2221-2-06.

Zajączkowski, W. (2006, 28 lipca). Notatka informacyjna nt. bieżącej sytuacji na Ukrainie (stan na 28 lipca br.) AMSZ, nr zespołu 180/09, w. IV, DW-Ua-2221-06.

Zajączkowski, W. (2006, 3 kwietnia). Notatka informacyjna nt. obserwacji wyborów parlamentarnych na Ukrainie $w$ dniu 26 marca 2006 r. AMSZ, nr zespołu 180/09, w. IV, t. DW-Ua-2221-06.

Zajączkowski,W. (2006, 7 sierpnia). Notatka informacyjna nt. powołania rzadu na Ukrainie. AMSZ, nr zespołu 180/09, w. IV, DW-Ua-2221-2-06.

Zajączkowski, W. (2006, 19 stycznia). Notatka z rozmowy z P. Tapiola, asystentem J. Solany ds. Ukrainy, Mołdawii i Białorusi 17 stycznia br. AMSZ, nr zespołu 180/09, w. IV, t. DW-Ua-223-06.

Zajączkowski, W. (2006, 9 lutego). Pilna notatka informacyjna $w$ sprawie doniesień prasy ukrainskiej nt. podpisania pakietu niejawnych ukrainsko-rosyjskich porozumień gazowych w dniu 4 stycznia br. AMSZ, nr zespołu 180/09, w. IV, DW-Ua-223-06.

\section{Druki zwarte}

Давидович, Я.В. (red). (2006). Вибори до Верховної Ради України 2006 року. Кн. 1. Київ.

Вибори до Верховної Ради України 2006 року. Інбормаційно-аналітичний збірник. (2006). Київ.

\section{Publikacje elektroniczne}

Springer, D. (2005, 3 grudnia). Ukraina: Nowa organizacja inauguruje działalność. Pobrane z: http://www.psz.pl/162-wschod/ukraina-nowa-organizacja-inaugurujedzialalnosc.

Бориславський, Л. (2006). Парламентські вибори-2006: недоліки і проблеми. Вісник Цебнтральної виборчої комісї, 2(4), 81-85. Pobrane z: http://www.cvk. gov.ua/visnyk/pdf/2006_2/visnyk_st_17.pdf.

Виборчий блок політичних партій «Блок Наталії Вітренко». Pobrane z: http:// www.cvk.gov.ua/pls/vd2002/webproc12v?kodvib=400\&pf7171=193.

Генпрокуратура закрила справу проти Порошенка (оновлено). (2005, 21 жовтня). Pobrane z: https://ua.korrespondent.net/ukraine/262228-genprokuratura-zakrilaspravu-proti-poroshenka-onovleno. 
Лещенко, С. (2014,22 травня). Три плями Петра Порошенка. Pobrane z: https://www. pravda.com.ua/articles/2014/05/22/7026138.

Партия политики Путина переименовалась в Русь единую. (2009, 11 марта). Роbrane z: https://korrespondent.net/ukraine/politics/768935-partiya-politiki-putina -pereimenovalas-v-rus-edinuyu.

«Партія політики Путіна» змінила назву на "Русь єдина». I це в Україні. (2009, 11 березня). Pobrane z: https://zik.ua/news/2009/03/11/partiya_polityky_putina_ zminyla_nazvu_na_rus_iedyna_i_tse_v_ukraini_172811.

Підсумки голосування по партіях (виборчих блоках партій). (2002, 31 березня). Pobrane z: http://www.cvk.gov.ua/pls/vd2002/webproc0v.

Протокол Центральної Виборчої Комісії про результати виборів народних депутатів України. (2006). Pobrane z: http://www.cvk.gov.ua/info/protokol_cvk_ 2006.pdf.

Сорока, С. (2010, 8 січня). Ющенко: хроніка зростання і падіння. Pobrane z: ttps:// www.pravda.com.ua/articles/2010/01/8/4589410/; Перший Уряд Юлії Тимошенко, http://batkivshchyna.te.ua.

Текст коаліційноӥ угоди. (2006, 21 июня). Pobrane z: https://www.obozrevatel.com/ news/2006/6/21/119716.htm.

Текст передвиборної програми Партії регіонів. (2005). Pobrane z: http://webcache. googleusercontent.com/search?q=cache:b5o_kh8WIOYJ:www.cvk.gov.ua/pls/ vnd2006/printblob\%3Fpf7171\%3D4\%26kodvib\%3D600+\&cd=1\&hl=pl\&ct=cln$\mathrm{k} \& \mathrm{gl}=\mathrm{pl} \& \mathrm{client}=$ firefox-b.

Універсал національної єдності. Текст, підписаний на круглому столі. (2006, 3 серпня). Pobrane z: https://www.pravda.com.ua/articles/2006/08/3/3139284.

Центр Разумкова (2006). 3 травня 2006 року в Україні в повному обсязі вступили в дію положення політичної реформи (зміни до Конституції, згідно з якими Президент втратив частину повноважень на користь Верховної Ради і Уряду). Чи відомо Вам про иее? Pobrane z: http://old.razumkov.org.ua/ukr/poll.php?poll_id=213.

Центр Разумкова (2006а). Як би ви поставилися до скасування змін до Конституції, внесених 8 грудня 2004р., та відновлення системи влади, яка існувала до иього?. Pobrane z: http://old.razumkov.org.ua/ukr/poll.php?poll_id=215.

Центр Разумкова (2006b). Як нові положення Конституції вплинули на такі аспекти діяльності влади? (ебективність, відкритість, підзвітність). Роbrane z: http://old.razumkov.org.ua/ukr/poll.php?poll_id=214.

Центр Разумкова (2007). Яким чином повинен формуватись Уряд в Україні? (динаміка, 2002-2007). Pobrane z: http://old.razumkov.org.ua/ukr/poll.php?poll_id=101.

Центр Разумкова (2007а). Яку систему виборів до Парламенту Ви вважаєте найкращою для Украйни? (динаміка, 2001-2007). Pobrane z: http://old.razumkov. org.ua/ukr/poll.php?poll_id=99.

Центр Разумкова (2008). Чи вважаєте Ви, щзо зміни до Конституиії України можуть допомогти країні вийти з кризи? Pobrane z: http://old.razumkov.org. ua/ukr/poll.php?poll_id=381.

Центр Разумкова (2008а). Чи виконує Президент України Віктор Ющенко свої передвиборні обіиянки? Pobrane z: http://old.razumkov.org.ua/ukr/poll.php?poll_ $\mathrm{id}=385$. 
Центр Разумкова (2008b). Чи виконує Прем'єр-міністр України Юлія Тимоменко свої передвиборні обіиянки?. Pobrane z: http://old.razumkov.org.ua/ukr/poll. php?poll_id=386.

Центр Разумкова (2012). Як Ви оцінюєте нинішні відносини України з Росією? (динаміка 2001-2012, регіональний розподіл). Pobrane z: http://old.razumkov. org.ua/ukr/poll.php?poll_id=839.

Центр Разумкова (2015). Якби наступної неділі відбувався реберендум щодо вступу України до НАТО, як би Ви проголосували? (динаміка, 2002-2015). Pobrane z: http://old.razumkov.org.ua/ukr/poll.php?poll_id=46.

Центр Разумкова (2015а). Який напрям зовнішньої політики має бути пріоритетним для України? (динаміка, 2002-2015). Pobrane z: http://old.razumkov.org.ua/ukr/poll.php?poll_id=305.

\section{Strony internetowe}

Батьківщина. Pobrane z: https://ba.org.ua.

Партія Регіонів. Pobrane z: https://www.rbc.ua/ukr/vyboru2012/party/p1.

Партія „Реформи і порядок”. (2002). Pobrane z: https://web.archive.org/web/201 20125123348/http://party.civicua.org/d0059812.htm.

Соціал-демократична партія України. Pobrane z: http://www.sdpuo.com.

Українська народна партія «Собор». Pobrane z: https://web.archive.org/web/2007 1031010020/http://party.civicua.org/d0203486.htm.

Вісник Центральної виборчої комісії (2007), 1. Pobrane z: http://www.cvk.gov.ua/ visnyk. 